\title{
Raban Maur
}

\section{HOMILIE O NAJWAŻNIEJSZYCH ŚWIĘTACH ORAZ O CNOTACH (WYBÓR)}

\author{
(Homiliae de festis praecipuis, item de virtutibus)
}

\section{WSTĘP}

Podczas audiencji generalnej w dniu 3 czerwca 2009 r. Papież Benedykt XVI powiedział: „Wspominany często jako praeceptor Germaniae, Raban Maur był niezwykle płodnym autorem. Dzięki swojej absolutnie wyjątkowej pracowitości przyczynił się być może bardziej niż wszyscy inni do podtrzymania żywotności owej kultury teologicznej, egzegetycznej i duchowej, z której miały czerpać następne wieki”1.

Urodzony ok. 780 r. w Moguncji, doskonale wykształcony, Raban stał się bardzo wpływową postacią swojej epoki - czasów Karola Wielkiego $(† 814)^{2}$ i Ludwika Pobożnego $(† 840)^{3}$, a więc okresu odnowy karolińskiej. Jako dziecko został oddany do klasztoru w Fuldzie, gdzie przygotowywał się do życia monastycznego. Pod kierunkiem Alkuina $(† 804)^{4}$ pogłębiał wiedzę teologiczną i artes liberales. Alkuin dal mu przydomek „Maurus”, który nosił ulubiony uczeń św. Benedykta $(† 547)^{5}$. W 814 r. Raban Maur otrzymał święcenia kapłańskie. W 822 r. został opatem klasztoru w Fuldzie, a 847 r. został mianowany arcybiskupem Moguncji. Zmarł w roku $856^{6}$. Był egzegeta, filozofem i poeta. W bogactwie dorobku teologicznego Rabana Maura znaczące miejsce zajmują wyjaśnienia egzegetyczne prawie wszystkich ksiag Starego i Nowego Testamentu. W dorobku tym znajduje się także ponad 230 homilii. W wydaniu Migne'a ${ }^{7}$ podzielone one zostały na dwie części. Część pierwsza jest zatytułowana Homiliae de festis praecipuis, item de virtutibus i liczy 70 homilii. Jest ona

\footnotetext{
${ }^{1}$ Benedetto XVI, Padri e scrittori del primo millennio. Rabano Mauro [udienza generale 3 VI 2009], w: Insegnamenti di Benedetto XVI 5/1 (2009) 965, przekład: Benedykt XVI, Raban Maur [audiencja generalna 3 czerwca 2009 r.], OsRomPol 30 (2009) nr 9 (316) 42.

${ }^{2}$ Por. R. Sawa, Karol Wielki, EK VIII 878-880.

${ }^{3}$ Por. R. Kras, Ludwik I Pobożny, EK XI 161.

${ }^{4}$ Por. U. Borkowska, F. Gryglewicz, Alkuin, EK I 375-376.

${ }^{5}$ Por. P. Szczaniecki, Benedykt z Nursji, EK II 228-230. Na temat Maura, ucznia św. Benedykta, por. S. Gregorius Magnus, Dialogorum libri IV II 3, 20; IV 3; VI 3; VII 2 i 4; VIII 9.

${ }^{6}$ Por. M. Kieling, Formacja duchownych w świetle „De institutione clericorum” Rabana Mau$r a, \operatorname{VoxP}(2006)$ t. 49, 277-288, spec. s. 277-278.

${ }^{7}$ Por. PL 110, 9-468.
} 
poprzedzona wstępem (praefatio) adresowanym do arcybiskupa Hajstulfusa $(\dagger 825)^{8}$. Część druga, o wiele obszerniejsza, licząca 163 homilie, jest zatytułowana Homiliae in Evangelia et Epistolas i także jest poprzedzona wstępem (praefatio) - dedykacją skierowaną w tym przypadku do króla Lotara I († 855). Raban przypomina, że posłał już królowi zbiór homilii obejmujący czas od Narodzenia Pańskiego do Wigilii Wielkanocnej, a obecnie przesyła homilie na okres od Wielkanocy do XV Niedzieli po Zesłaniu Ducha Świętego; w przyszłości zaś ma jeszcze posłać królowi homilie na pozostały czas roku kościelnego.

We wstępie do pierwszej części Raban omawia jej zawartość pisząc do Hajstulfusa:

„Posłuszny twoim rozkazom, świątobliwy ojcze, przygotowałem kazania do ludu o wszystkim, co - jak uznałem - jest dla nich konieczne. Po pierwsze, jak powinni obchodzić główne święta w ciągu roku, aby powstrzymując się od zajęć światowych, nie byli pozbawieni słowa Bożego, lecz poznając wolę Bożą, starali się wypełniać ją czynami. Po drugie, przygotowaliśmy dla nich zbiór kazań na temat różnych rodzajów cnót, to jest wiary, nadziei i miłości, czystości, wstrzemię́liwości i o pozostałych rodzajach cnót - o tym, aby dążąc do nich i strzegąc ich, podobali się Bogu i mogli otrzymać życie wieczne w niebie ze świętymi aniołami. Następnie zaś dołączyliśmy inne kazania o rozmaitych skłonnościach do grzechów i wad, którymi starodawny wróg oszukuje i zwodzi rodzaj, to jest o złu pychy i próżności, gniewu, zawiści, oszustwa, skąpstwa, łakomstwa i nieczystości, i o tym podobnych; aby owce Chrystusowe wiedziały, jak uniknąc ukąszeń bardzo okrutnego wilka i bardzo srogiego smoka oraz mogły się przed ich napaścią ustrzec".

W dalszym ciągu Raban usprawiedliwia się, że z powodu rozmaitych przytrafiających mu się zajęć nie mógł wydać homilii za jednym razem, ale czynił to w zależności od tego, jak pozwalały mu na to okoliczności, posyłając Hajstulfusowi oddzielnie poszczególne teksty. Prosi więc go, aby zechciał wszystko zebrać w jeden zwój i poprzedzić jako wstępem pisanym właśnie do niego listem ${ }^{10}$.

${ }^{8}$ Por. Annales Xantenses qui dicuntur, ed. B. de Simson, MGH Scriptores Rerum Germanicarum XII, Hannoverae - Lipsiae 1909, 6: „Anno DCCCXXV. Haistulfus archiepiscopus Magontiae civitatis obiit, et successit in locum eius Otgerus capellanus dominicus".

${ }^{9}$ Rabanus Maurus, Epistula ad Haistulfum archiepiscopum, PL 110, 9: „Iussionibus tuis obtemperans, beatissime Pater, sermonem confeci ad praedicandum populo, de omnibus quae necessaria eis credidi; hoc est, primum qualem observantiam deberent habere in festivitatibus praecipuis quae sunt in anni circulo, ut vacantes ab opere mundano, non vacui fierent a verbo divino, sed cognoscentes Dei voluntatem, factis eam implere studerent: deinde texuimus praedicationem illis de diversis speciebus virtutum, id est, de fide, spe et charitate, de castitate, continentia, et caeteris speciebus virtutum, qualiter eas appetentes et custodientes Deo placerent, et vitam aeternam in coelis cum sanctis angelis percipere possent. Postea vero alium adiunximus sermonem de variis errorum et vitiorum seductionibus cum quibus antiquus hostis humanum genus deludit ac decipit: hoc est, de malo superbiae et iactantiae, irae, invidiae, fraudis, avaritiae, gulae et fornicationis, et his similibus, ut scirent Christi oves quomodo lupi ferocissimi et draconis saevissimi morsus evadere, et praevisos cavere possent", thum. własne.

${ }^{10}$ Por. tamże. 
Niżej zamieszcza się pierwszy polski przekład dziewiętnastu homilii wybranych z pierwszej części zbioru: Homiliae de festis praecipuis, item de virtutibus. Są wśród nich homilie na czas przed Narodzeniem Pańskim (czyli na adwent), homilie na Narodzenie Pańskie i inne dni z tym świętem związane, homilie wielkotygodniowe - od Niedzieli Palmowej do Niedzieli Wielkanocnej, następnie homilie na niedziele i święta okresu wielkanocnego, wreszcie na kilka świąt przypadających po Zesłaniu Ducha Świętego, mianowicie na Narodzenie św. Jana Chrzciciela oraz na Narodzenie i na Wniebowzięcie Najświętszej Maryi Panny.

Cytaty z Pisma Świętego obecne w homiliach zostały przełożone przez thumaczy. Odsyłacze do nich podano w tekście przekładu; numeracja psalmów i sigla biblijne stosują się do zasad zastosowanych w Biblii Tysiąclecia.

\section{WYDANIA TEKSTU}

J.P. Migne: $\quad$ Parisiis 1852 lub 1864, PL 110, 9-468.

\section{BIBLIOGRAFIA}

R. Kottje, Hrabanus Maurus, „Praeceptor Germaniae”?, „Deutsches Archiv für Erforschung des Mittelalters" 31 (1975) 534-545; M. Rissel, Rezeption antiker und patristischer Wissenschaft bei Hrabanus Maurus, Lateinische Sprache und Literatur des Mittelalters 7, Bern - Frankfurt 1976; Rabanus Maurus in seiner Zeit 780-1980, hrsg. W. Weber, Mainz 1980; M. Sandmann, Hraban als Mönch, Abt und Erzbischof, „Fuldaer Geschichtsblätter” 56 (1980) 113-180; F.W. Bautz, Hrabanus Maurus, BBKL II 1090-1093; Hrabanus Maurus - Profil eines europäischen Gelehrten. Beiträge zum Hrabanus-Jahr 2006, hrsg. N. Kössinger, St. Ottilien 2008; Raban Maur et son temps, ed. P. Depreux - S. Lebecq - M.J.L. Perrin - O. Szerwiniack, Haut Moyen Âge 9, Turnhout 2010.

\section{PRZEKŁAD}

\section{Homilia I: Przed świętem Narodzenia Pana naszego Jezusa Chrystusa ${ }^{11}$}

Bracia umiłowani! Ponieważ zbliżają się najświętsze obchody czasu, w którym nasz Zbawca przez swe miłosierdzie raczył narodzić się wśród ludzi, zatem dogłębnie rozważcie, w jaki sposób powinniśmy się przygotować na przybycie tak wielkiej mocy, byśmy stali się godni przyjąć naszego Króla i Pana z weselem, wśród radości i chwały, i byśmy przed Jego obliczem zasłużyli raczej na radosne wkroczenie do grona świętych niż na wieczne, hańbiące oddalenie od Niego, spowodowane naszymi grzechami. Dlatego też proszę i napominam, abyśmy przy pomocy Bożej pracowali, ile tylko zdołamy, abyśmy owego dnia mogli przystapić do ołtarza Bożego ze szczerym i czystym

\footnotetext{
${ }^{11}$ Przekładu dokonano na podstawie wydania J.P. Migne, PL 110, 10-12; thum. Natalia Turkiewicz.
} 
sumieniem, sercem wolnym od win i niesplamionym ciałem i byśmy mogli przyjąć Jego Ciało i Krew - nie z obawy przed sądem Bożym, lecz jako lekarstwo dla naszej duszy. W Ciele Chrystusa trwa bowiem nasze życie; sam Pan rzekł: ,Jeśli nie będziecie spożywać Ciała Syna Człowieczego i nie będziecie pić Krwi Jego, nie będziecie mieli życia w sobie" (J 6, 53). Musi odmienić swoje życie ten, kto chce je zachować. Jeśli bowiem nie odmieni grzesznego życia i nie zacznie postępować sprawiedliwie, będzie przyjmował Ciało Chrystusa, które jest prawdziwym życiem, ze względu na sąd Boży. To zaś bardziej zdeprawuje go niż uświęci, w większym stopniu pozbawi życia niż je zachowa. Tak bowiem rzecze Apostoł: „Kto w sposób niegodny spożywa Ciało Pańskie i pije Krew Jego, ten je i pije osąd na siebie” (1Kor 11, 29). I trzeba, aby w każdym czasie Pan znajdował nas ozdobionych dobrymi uczynkami i jaśniejących, zwłaszcza jednak w dniu Narodzenia Pańskiego, jak sam powiedział w Ewangelii, iż nasze dobre czyny powinny jaśnieć blaskiem wobec ludzi, aby we wszystkich Bóg został uwielbiony.

Zważcie dokładnie, bracia. Jeśli jakikolwiek władca ziemski albo inny możny człowiek zaprosiłby was na urodzinową ucztę, to staralibyście się przyodziać w jak najnowsze, najwspanialsze, najbardziej ozdobne szaty, aby nie raziło oczu gospodarza ich zużycie, zniszczenie ani ubóstwo. Zatem z takim samym staraniem, jak tylko zdołacie, z pomocą Chrystusa dążcie do tego, aby dusze wasze, ozdobione blaskiem wszelakich cnót - klejnotami prostoty i kwieciem wstrzemięźliwości, z czystym sumieniem przystapiły do świętowania wieczności, czyli Narodzenia Zbawiciela Pana. Zadbajcie, by lśniły blaskiem czystości, jaśniały miłością, rozsiewały światło miłosierdzia, sprawiedliwości i pokory, nade wszystko zaś promieniały umiłowaniem Boga. Chrystus Pan bowiem, skoro pozna, że tak przyozdobieni święcicie Jego Narodzenie, sam raczy zstąpić i nie tylko nawiedzić dusze wasze, lecz spoczać w nich i zamieszkać na zawsze, tak jak to zostało napisane: „Oto bowiem ja zstąpię i zamieszkam w nich, i będę w nich przebywał, i oni będą mi ludem, a ja będę im Bogiem" (por. Ez 37, 27) - mówi Pan Bóg.

O, jakże szczęśliwa jest dusza, która dzięki dobrym uczynkom zasłuży na to, by przyjąć Chrystusa do siebie jako gościa i mieszkańca! Pozostaje na zawsze radosna, pełna wesela i promienna, wolna od niebezpieczeństwa grzechu. I przeciwnie - jak bardzo nieszczęsne jest sumienie, które tak bardzo poraniło się niegodziwymi czynami, że nie Chrystus w niej spoczywa, lecz panuje w nim diabeł. Dusza taka, jeśli szybko nie zażyje leku, jakim jest pokuta, oddali się od światłości, a ogarnie ją ciemność; wyzbędzie się łagodności, a napełni się gorycza; oderwie się od życia, a osnuje ją śmierć. Kogo jednak ogarnie taki stan, niech nie złorzeczy miłosierdziu Bożemu i niech nie pozwoli się złamać śmiertelnej rozpaczy, lecz tym prędzej zwróci się ku skrusze. Jeśli wciąż palą go świeże rany grzechów, niech podda się leczniczej mocy łez, ponieważ nasz Lekarz jest wszechmocny i tak potrafi opatrywać nasze rany, że 
nie zostają nawet ślady blizn. Wierzmy tylko w Niego i trwajmy co sił w dobrym postępowaniu, i nigdy nie wątpmy w Jego miłosierdzie.

Bracia umiłowani, ci, co dogłębnie rozważają te sprawy i trwają w dobru, niech przy pomocy łaski Bożej obstają przy sprawiedliwym postępowaniu, ponieważ zbawiony będzie nie ten, kto uczyni pierwszy krok, lecz ten, kto wytrwa do końca. Ci zaś którzy wiedzą że są opieszali w uczynkach miłosierdzia, gotowi do gniewu i lubują się w uprawianiu rozwiązłości, niech przy Bożej pomocy śpiesznie wyrwą się z władzy zła i próbują spełnić wszelkie możliwe dobro, aby, kiedy nadejdzie dzień sądu, nie zostali pokarani wraz z upadłymi i grzesznikami, lecz razem z innymi sprawiedliwymi i miłosiernymi zasłużyli na wieczną nagrodę za przewodnictwem Jezusa Chrystusa, Pana naszego, który z Ojcem i Duchem Swiętym żyje i króluje na wieki wieków. Amen.

\section{Homilia II: Przed świętem Narodzenia Pańskiego ${ }^{12}$}

Bracia umiłowani! Kiedy chcecie świętować uroczystość któregokolwiek ze świętych w ciągu roku, poweźmijcie mocne postanowienie, że z największym staraniem przyozdobicie się we wszelkie cnoty, abyście stali się godni przystapić do niebiańskiej uczty i wejść do radości wspólnoty świętych, do której dążycie. Albowiem na niebiańskim stole nie ma ludzkiego pożywienia, a znajduje się tam chleb anielski, jak to zostało napisane: „Dał im chleb z nieba, chlebem anielskim pożywił się człowiek" (por. Ps 77, 24). Niech zatem, według słów Apostoła, wejrzy człowiek na siebie samego i niech spożywa ten chleb, i niech pije z tego kielicha.

Chrystus bowiem, Pan nasz, chociaż po męce zmartwychwstał i wstapił do nieba, to jednak, jak wierzymy, z uwaga przygląda się i rozważa, do jakiego stopnia każdy z Jego sług przygotowuje się i przysposabia do obchodów wspomnień świętych Pańskich, a w szczególności do świąt Jego Narodzenia - bez chciwości, gniewu, pychy i swawoli. I w zależności tego, jak wielkie bogactwo dobrych uczynków ujrzy, na miarę tego udzieli człowiekowi łaski i miłosierdzia. Jeśli bowiem ujrzy kogoś przyodzianego w światło miłości, w ozdobie pereł sprawiedliwości i wielkoduszności, a ponadto czystego, pokornego, łagodnego, litościwego, pełnego cierpliwości i umiarkowania, wówczas pozwoli mu przystapić do stołu, spożywać swoje Ciało i Krew za pośrednictwem posługi kapłanów - i nie po to, by poddawać sądowi, lecz jako lekarstwo. Jeśli zaś ujrzy kogoś pełnego obłudy, skłonnego do pijaństwa, chciwego, pysznego, zawistnego, podstępnego, zachłannego, jeśli ujrzy oszczercę lub krzywdziciela, to obawiam się, że powie mu tak, jak to rzekł w Ewangelii: „Przyjacielu, jakże tu wszedłeś, nie mając weselnej szaty?” (Mt 22, 12). I ponieważ Bóg się odwróci, stanie się to, co następuje: „Zwiążcie mu ręce i nogi i wyrzućcie go na zewnątrz, w ciemności; tam będzie płacz i zgrzytanie zębów” (Mt 22, 13).

\footnotetext{
${ }^{12}$ Przekładu dokonano na podstawie wydania J.P. Migne, PL 110, 12-13; thum. Natalia Turkiewicz.
} 
Oto, jaki wyrok otrzyma w dniu sądu ten, kto przystąpi do święta Pańskiego bez uzdrowicielskiej mocy pokuty, skażony zmazą win.

I dlatego, bracia, kiedy zbliża się czy to święto Narodzenia Pańskiego, czy to inne uroczystości, na długo przedtem zachowajcie wstrzemięźliwość zarówno w odniesieniach pozamałżeńskich, jak i powstrzymajcie się od obcowania z własnymi żonami; nie pozostawiajcie w sercu nienawiści do nikogo, tak bowiem jak poprzez łakomstwo znika nicość, sprawiedliwość według miłosierdzia odpłaca ubogim. Są bowiem tacy, co uważają że pijaństwo jest bardzo małym grzechem, albo nie jest nim wcale, i nie pamiętaja, że Pan powiedział do swych apostołów: „Strzeżcie się, aby serca wasze nie stały się ociężałe wskutek obżarstwa i pijaństwa, i trosk życia doczesnego, i aby dzień ów nie nadszedł dla was niespodzianie; zguba bowiem dosięgnie wszystkich, co mieszkają na całej ziemi” (Łk 21, 34-35). Apostoł zaś powiedział: „Nie upijajcie się winem, które niesie rozpustę” (Ef 5, 18). I jeszcze: „Czy nie wiecie, że niegodni nie posiądą Królestwa niebieskiego? Strzeżcie się błędu, bowiem ani rozpustnicy, ani bałwochwalcy, ani bezwstydnicy, ani gorszyciele, ani ci, co obcują z mężczyznami, ani okrutnicy, ani skąpcy, ani opoje, ani bluźniercy, ani łupieżcy nie posiądą Królestwa Bożego” (1Kor 6, 9-10). I prorok mówi: „Biada tym, co wstają rano dla pijaństwa, po to, by pić aż do wieczora i rozgrzewać się winem" (Iz 5, 11). I jeszcze: „Biada wam, którzy jesteście mocni w piciu wina i śmiele mieszacie trunki” (Iz 5, 22). Tak więc, ktokolwiek miałby skłonności do pijaństwa i chciałby innych do niego nakłonić i pociagnąć, w owym dniu sądu zostanie obwiniony za siebie i za tamtych, i zda rachunek Panu.

Lecz skoro teraz jaśnieje nam dzień Narodzenia Pańskiego, oczyśćcie się, bracia, z wszelkiej zmazy grzechu, i jeszcze gorliwiej przysposóbcie się dobrym postępowaniem; powstrzymajcie się od obcowania z żonami waszymi, nie pożądajcie cudzej rzeczy ani żony, nie odbierajcie drugiemu jego własności ani siła, ani podstępem, często zwołujcie ubogich, by z wami siadali do stołu. Przybywajcie też wcześniej na święte czuwania - pozostając w kościele, módlcie się lub śpiewajcie psalmy. Powstrzymajcie swoje usta przed wypowiadaniem słów próżnych i bezmyślnych, i innych również w tej sprawie upominajcie. Żyjcie w pokoju ze wszystkimi, a jeśli spostrzeżecie kłótnika, nawołujcie do zgody. Jeśli zechcecie przy pomocy Chrystusa wypełniać te zalecenia i w tym czasie będziecie mogli przystapić do ołtarza Bożego z czystym sumieniem, to i w przyszłym świecie wstąpicie do wiecznej szczęśliwości.

\section{Homilia III: O poście grudniowym ${ }^{13}$}

Umiłowani! Zaiste wspaniała łaska Boża każdego dnia działa w sercach chrześcijan, aby wszystkie nasze pragnienia odwrócić od spraw ziemskich, a skierować je ku rzeczom niebiańskim. Lecz również życie doczesne trwa

\footnotetext{
${ }^{13}$ Przekładu dokonano na podstawie wydania J.P. Migne, PL 110, 13-14; thum. Natalia Turkiewicz.
} 
dzięki mocy Stworzyciela i podtrzymywane jest przez Jego Opatrzność. Ten bowiem, który jest szafarzem dóbr przemijalnych, jest także poręczycielem wieczności. Wszystko, co rodzi się dla pożytku ludzkiego - zboża, winnice, drzewa oliwne - wypływa z dobroci Boga, tak różnorodnej w swych przymiotach. Dobroć ta łagodnie wspiera nikłe wysiłki rolników, aby wiatry i deszcze, chłód i upał, dni i noce służyły naszemu pożytkowi. Niewiele bowiem zdziała wiedza człowieka w jego pracach, jeśli do zwyczajowych zasiewów i nawodnienia nie przyłoży ręki sam Bóg. Dlatego dobre jest i sprawiedliwe, byśmy wspierali także innych z tych dóbr, którymi obdarzył nas Ojciec niebieski. Jest bowiem wielu takich, co nie mają swojego udziału ani w polach uprawnych, ani w winnicach, ani w zbiorach oliwek. Ich niedostatek powinno się wyrównać stosownie do tego, jak Pan nasz rozdzielił dostatek, aby i oni wysławiali Boga za urodzajność ziemi i cieszyli się, że została powierzona takim właścicielom, a także stała się rzeczą wspólną dla biednych i pielgrzymów. Dlatego też Bóg w swej sprawiedliwości darował im pracę, aby biednych uwieńczyć za ich cierpliwość, a miłosiernych za łaskawość ${ }^{14}$.

Każdy czas, umiłowani, jest odpowiedni dla wypełniania tego dzieła, a teraz nastała po temu pora wyjątkowo odpowiednia i właściwa. Na ten czas bowiem nasi święci ojcowie, pouczeni przez Prawo i natchnieni przez Boga, wyznaczyli post dziesiątego miesiąca, aby rozumna wstrzemięźliwość, oddzieliwszy się od wszelkich pokus, została ofiarowana Bogu, i aby każdy pamiętał, żeby tak wykorzystać nadmiar, który posiada, aby wobec siebie tym większą stosować powściągliwość, a wobec biednych - tym większą hojność. Jałmużna i post bowiem to wielce skuteczne przebłaganie za grzechy, i szybciej do Boskich uszu dociera modlitwa, wzniesiona przez takie pośrednictwo. I nic dla nikogo nie jest tak bardzo jego własnością jak to, co oddaje najbliższym. Część bowiem z cielesnych możliwości, które są udzielone potrzebującym, przeistacza się w skarb wieczny.

Zatem, bracia, skoro mamy przyjąć Narodzenie Pańskie, oczyśćmy się z wszelkiej zmazy występku, a napełnijmy skarbiec wszelakimi darami, aby w owym świętym dniu stamtąd czerpali pielgrzymi, pokrzepiły się wdowy, ubodzy się przyodziali, aby za sprawą wielu została za nas spłacona Bogu danina łask i dopełniła się nasza ofiara uświęcona w Duchu Świętym. Zachowujmy zatem post w środę i piątek w tym tygodniu; w sobotę zaś wspólnie, już uwolnieni od postu, należycie spełnijmy najświętszą ofiarę przy relikwiach

${ }^{14} \mathrm{~W}$ tekście oryginalnym homilia jest zatytułowana: De ieiunio decimi mensis. Chodzi o tzw. Suche Dni w grudniu (December był w starożytnym Rzymie dziesiątym miesiącem roku, gdy rok zaczynał się w marcu), czyli quattuor tempora adventus, po III niedzieli adwentu, obchodzone w liturgii rzymskiej do czasu reformy II Soboru Watykańskiego i obecne dzisiaj w liturgii sprawowanej in forma extraordinaria. Na początku każdej nowej pory roku Kościół dedykował trzy dni tygodnia - środę, piątek i sobotę - na post i modlitwę, dla uproszenia błogosławieństwa Bożego dla ludzkiej pracy oraz dla duchownych i dlatego w sobotę suchych dni zimowych przez wieki udzielano święceń. Suche Dni w grudniu miały także charakter przygotowania do świąt Narodzenia Pańskiego. W tym miejscu homilii mamy wyraźne nawiązanie do wątku dziękczynienia za plony w Suche Dni. 
świętych, których czcimy w tym miejscu. Uczyńmy to zaś szczególnie na pamiątkę świętego Piotra Apostoła, gdyż tego dnia przy jego uświęconym ciele wypełnia ofiarę Kościół rzymski ${ }^{15}$. Ten bowiem święty apostoł wraz z innymi świętymi Boga (jak przeczuwamy i wierzymy) nieustannie otacza opieką pasterską owce powierzone mu przez Pana, zanosząc modły i błagania za Kościół Boży, który, ustanowiony dla Jego uwielbienia, powinien być uwolniony od wszelkiego błędu i trwać umocniony w słusznej wierze i dobrym postępowaniu.

\section{Homilia IV: O Narodzeniu Pana naszego Jezusa Chrystusa ${ }^{16}$}

Proszę was, bracia najmilsi, abyście ochoczo przyjęli słowa, które Pan wyrzeknie w dniu tak słodkim, w którym skrucha przychodzi na niewiernych i grzeszników, w którym niewdzięcznik dotknięty zostaje miłosierdziem, żałujący ma nadzieję na łaskę, więzień nie wątpi o wyzwoleniu, zraniony pragnie lekarstwa, w którym rodzi się „Baranek, co gładzi grzechy świata” (J 1,29). Oto Chrystus, nade wszystko nasz Zbawiciel, a w Jego Narodzenie ten, kto ma sumienie spokojne, doznaje miłej pociechy, kto niegodziwe, tym bardziej się lęka; kto jest sprawiedliwy, modli się gorliwie, kto grzeszny, najgoręcej prosi o łaskę: Jakże słodki dzień, zaprawdę słodki, niosący przebaczenie wszystkim, którzy żałują za grzechy. Zapewniam was, drodzy synowie, i przekonany jestem, że jeśliby ktoś w tym dniu żałował serdecznie, a nie wracał do wymiocin swych grzechów, to o cokolwiek by poprosił, będzie mu dane, jeśli tylko nie zwątpi w wierze i ku żądzom znów się nie zwróci. Dziś zostaje zgładzony grzech całego świata, a grzesznik ma waţpić? Zważcie jednak, jaką winna być pokuta, bo wielu ciaggle mówi o swej grzeszności, a przecież grzech ich cieszy: jest to przyznanie się, ale nie poprawa; dusza się uskarża, ale się nie leczy. Prawdziwą poprawę zapewnia jedynie wstręt do grzechu i miłość Boga, kiedy ktoś tak się nawraca, że już nie popada w poprzedni stan; gdy tak się poprawia, że nie powraca do grzechu. Skoro dziś Pan się rodzi, najmilsi bracia, to Jemu samemu, naszemu Odkupicielowi, ślubujmy i śluby wypełnijmy, jak zostało napisane: „Ślubujcie i wypełnijcie ślub wobec Pana, Boga waszego" (Ps 76, 12); ślubujmy chętnie i z ufnościa, On da nam możność, byśmy mogli śluby wypełnić; my zaś miejmy nadzieję na spełnienie, cokolwiek byśmy Mu przyrzekli.

Niech jednak nikt nie sądzi, że mówiąc o przyrzeczeniu mam na myśli rzeczy znikome i przyziemne; każdy z nas składa w ofierze to, co w nim nasz Zbawiciel odkupił, to jest własną duszę. Jeśli zaś mnie spytasz, jakim sposobem ofiaruję moją duszę, którą On sam ma w swej władzy, odpowiem ci, iż przez

${ }^{15}$ Nawiązanie do tego, że liturgiczna stacja soboty Suchych Dni, w okresie adwentu, znajdowała się u Św. Piotra w Rzymie, gdzie po całodniowym poście wierni gromadzili się na czuwanie i modlitwę.

${ }^{16}$ Przekładu dokonano na podstawie wydania J.P. Migne, PL 110, 14-16; thum. ks. Jarosław Adamiak. 
święty sposób życia, czyste zamiary, pożyteczne uczynki, odwrócenie się od zła, zwrócenie się ku dobru, odrzucenie wad, ukochanie Boga, miłość bliźniego, świadczenie miłosierdzia biedakom, bo przecież sami byliśmy biedni nim zostaliśmy odkupieni; dalej przez przebaczenie tym, którzy przeciw nam grzesza, bośmy wszyscy byli pod władzą grzechu; przez niweczenie pychy, bo przez pychę zwiedziony został pierwszy człowiek; przez odrzucenie zazdrości, bo poprzez zazdrość diabeł usidlił rodzaj ludzki. Jeśli ktoś był aż dotąd rozpustny, niechże ślubuje odtąd żyć w czystości; jeśli kto żywił zazdrość wobec brata, niech ją odrzuci i zamieni na życzliwość; jeśli ktoś dopuścił się zabójstwa, niech przyrzeknie dziś i odtąd zaraz wydaje godne owoce pokuty, ażeby sam siebie podwójnie nie skazał na nieszczęście, ponieważ niegodnie przyjmuje Ciało Pańskie; jeśli kto przywykł dla ubliżania i złorzeczeń posługiwać się językiem, niechże go skłoni raczej do modlitwy, by rozbrzmiewał chwałą Boga; jeśli ktoś pogrążony jest w pijaństwie, niech odtąd ślubuje trzeźwość; jeśli kto stał się gwałtowny, niech uczy się łagodności; jeśli kto siłą bądź też podstępem przywłaszczył sobie cudze dobra, niechże własnymi obdzieli biedaków; jeśli kto nazbyt często posługiwał się kłamstwem, niech odtąd mówi prawdę; jeśli ktoś czuje, że jest okrutnikiem, niech skłania się ku miłosierdziu; jeśli kto był hardy i nieustępliwy, niech przyrzeknie, iż pragnie nabyć pokory i posłuszeństwa wobec Boga i ludzi. A gdy wszystko to uczynicie, najmilsi bracia, złożycie Bogu miłą ofiarę, aniołowie zaś, którzy są stróżami waszego życia, przed obliczem boskiego majestatu takąż złożą ofiarę. A po jej złożeniu spłynie na was błogosławieństwo i zbawienie nieprzemijające i jak rzekł Salomon: „Przypominanie wasze nie ulegnie zapomnieniu" (Mdr 16, 11). A mówi się o was: Oto mój lud, który na własność nabyłem krwią swoją, nasycił mnie modłami i otoczył dymem z kadzideł: oto ja im będę jako Pan, oni sami zaś będą mi ludem. I nie będzie wśród nich więcej niewoli ni opuszczenia, mówi Pan Bóg.

Mając zatem taką obietnicę, najmilsi, oczyśćmy się od wszelkiej zmazy cielesnej i duchowej, dopełniając uświęcenia w bojaźni Bożej i starajmy się tak obchodzić tę obecną uroczystość, abyśmy zasłużyli na to, by rozkoszować się na wieki niebiańską radością świętych, jeśli tego udzieli sprawca niniejszej uroczystości, Pan nasz, Jezus Chrystus, który z Ojcem i Duchem Świętym żyje i króluje, Bóg przez wszystkie wieki wieków. Amen.

\section{Homilia V: Również na Narodzenie Pańskie ${ }^{17}$}

Radujmy się z całego serca w Panu, najmilsi, i cieszmy się duchową radością: bo oto zajaśniał dzień naszego odkupienia, ponownych narodzin, wiecznego szczęścia. Dzisiaj godzi się, byśmy z sercami wzniesionymi ku niebu wielbili Boską tajemnicę, ażeby to, co dokonało się z niezmiernej łaskawości

${ }^{17}$ Przekładu dokonano na podstawie wydania J.P. Migne, PL 110, 16-17; tłum. ks. Jarosław Adamiak. 
Boga, obchodzono wśród wielkich radości Kościoła. Wkracza bowiem Syn Boży w niskość tego świata zstępując z niebiańskiej stolicy, nie opuszcza jednak ojcowskiej chwały. Rodzi się według nowego porządku, a dlatego w nowym porządku, że - choć niewidzialny w swej [naturze] - dla nas staje się widzialny. Nieogarniony zechciał, by Go pojęto; choć pozostał przedwieczny, zaczął istnieć w czasie; choć Pan wszechrzeczy, przyjął postać sługi, przysłoniwszy wspaniałość swego majestatu. Choć jako Bóg nie doznaje cierpień, nie wzgardził człowieczeństwem podległym cierpieniu. Wreszcie, choć nieśmiertelny, poddał się jednak prawom śmierci.

Kimkolwiek więc jesteś, a chlubisz się z pobożnością i wiarą imieniem chrześcijanina, dar owej hojności z całą słusznością rozważ: tobie oto, którego odrzucono, boś się sprzeniewierzył, tobie, którego wygnano z rajskich przybytków, tobie, który umierasz na dalekim wygnaniu, tobie, który się w proch i pył rozpadłeś i który w życiu swoim nie miałeś już żadnej nadziei, przez Wcielenie Słowa została dana moc, abyś z oddali powrócił do swego Stwórcy, rozpoznając w Nim Ojca, abyś stał się wolny, zamiast być niewolnikiem, abyś z obcego stał się synem, abyś ty, który urodziłeś się w ciele podległym zepsuciu narodził się na nowo z Ducha Świętego i abyś odziedziczył dzięki łasce to, czego nie mogłeś mieć ze swej natury. Mając zatem ufność wobec tak wielkiej nadziei, najmilsi, wytrwajcie niewzruszenie w wierze, na której się oparliście. Przez odpowiednie postępowanie dojdźcie do tego, co się o was mówi: nosicie bowiem przedziwne imię waszego Pana i od Chrystusa nazwano was chrześcijanami. Będziecie nimi jednak rzeczywiście dopiero wtedy, gdy zachowywać będziecie Jego polecenia i wypełniać będziecie wolę Ojca niebieskiego.

Nie lekceważcie, bracia, waszych najuboższych braci, z którymi dzielicie przynależność do Chrystusa, ale częściej ich zapraszajcie do swego stołu, według polecenia Pana. Nie godzi się, by w tak wielką uroczystość, którą lud chrześcijański odnosi do jednego Pana, jedni się upijali, innych zaś dręczyło niebezpieczeństwo głodu. Bo i my, jak i cały lud chrześcijański, jesteśmy sługami jednego Boga, za jednaką cenę odkupieni, w takim samym położeniu weszliśmy na ten świat i w takim samym go opuścimy, jeśli zaś dobrze postępujemy, w równym stopniu dojdziemy do tej samej szczęśliwości. Czemu zatem ubogi nie miałby spożywać $\mathrm{z}$ tobą posiłku, skoro z tobą obejmie królestwo; czemuż nie ma przyjać okrycia, choćby i znoszonego, skoro razem z tobą przywdziać ma szatę nieśmiertelności; czemu ubogi nie miałby dostąpić spożywania twego chleba, skoro razem z tobą dostapił sakramentu chrztu; czemu nie jest godny przyjmować choćby resztek twego pożywienia, skoro wraz z tobą przybędzie na ucztę aniołów? Nad tym, bracia, usilnie rozmyślajcie i bez zwłoki starajcie się to wypełnić, ażebyśmy, gdy nadejdzie dzień sądu, wraz z tymi, którzy gardzą ubogimi, nie usłyszeli: „Odejdźcie precz ode mnie, przeklęci, w wiekuisty ogień" (Mt 25, 41), lecz byśmy wraz ze sprawiedliwymi i miłosiernymi zasłużyli, by usłyszeć: „Pójdźcie, błogosławieni Ojca mojego, obejmijcie w posiadanie królestwo: bo cierpiałem głód, a daliście mi jeść, pragnąłem, a daliście mi 
pić" (Mt 25, 34-35). Jakże upragniony głos pozwala nam usłyszeć dzisiaj narodzony Odkupiciel nasz, który żyje i króluje wraz z Ojcem w jedności Ducha Świętego, Bóg przez wszystkie wieki wieków. Amen.

\section{Homilia VI: Na Oktawę Narodzenia Pańskiego ${ }^{18}$}

Usłyszeliście w dopiero co odczytanej Ewangelii, najmilsi bracia, z jakiej przyczyny obchodzimy tak wzniosłą uroczystość. Oto, jak zapisał święty Łukasz ewangelista: „Po upływie ośmiu dni, gdy obrzezano chłopca, nadano Mu imię Jezus, którym został nazwany przez anioła zanim począł się w łonie [Matki]" (Łk 2, 21). Owo Dziecię zatem, które było na początku, było Słowem u Ojca, a Słowo to było Bogiem. Ono było od początku u Boga. Wszystko stało się przez Nie, a bez Niego nie stało się nic (por. J 1, 1-3).

Lecz cóż to znaczy, że ósmego dnia chłopiec został obrzezany, jeśli nie to, iż jakkolwiek jako prawdziwy Bóg zawsze przebywał u Ojca, to przecież ze względu na nas stał się prawdziwym człowiekiem i naprawdę przyjął ciało dla naszego zbawienia. Tak oto Chrystus Pan był jedną osobą w dwóch naturach, to jest $\mathrm{w}$ naturze boskiej i w naturze ludzkiej, tyle, że bez grzechu; jest tak rzeczywiście, o czym świadczy dalszy ciąg Ewangelii: „A Słowo ciałem się stało i zamieszkało między nami" $(\mathrm{J} 1,14)$. Zaiste więc Odkupiciel nasz po to zechciał się narodzić, aby, zgodnie ze [znaczeniem] swego imienia zbawić człowieka; złączył się też odpowiednio z każdym stanem. Zechciał być obrzezany zgodnie z Prawem, aby wykupić tych, którzy pod władzą Prawa się znajdowali. Nie wzdragał się też Pan przed tym, by za niego złożono w świątyni ofiarę, aby objawić się jako Odkupiciel tych, którzy od początku świata aż do czasów, gdy nakazano obrzezanie, podobali się Bogu spośród innych narodów i czy to przez składanie ofiar czy to przynajmniej przez samą cnotę wiary starali się uwolnić od pierwotnych więzów winy zarówno życie swoje, jak i swoich bliskich, polecając je Stwórcy. Na koniec wreszcie, to jest w trzydziestym roku swego życia, został ochrzczony przez Jana, aby ukazać, iż jest sprawcą naszego oczyszczenia oraz to, że On to jest Barankiem, który gładzi grzechy całego świata (por. J 1, 29). Ale i to, że w samym dniu swego obrzezania pozwolił, by wzywano go pod imieniem Jezus, uczynił naśladując dawne obyczaje: oto Abraham, który jako pierwszy poddał się obrzezaniu, w samym dniu owego obrzezania dla zasług swej wielkiej wiary, dostąpił tego, iż nazwano go Abrahamem, to jest ojcem wielu narodów (por. Rdz 17, 4), wcześniej zaś nazwano go dostojnym ojcem. W ten sam sposób wedle Prawa ci, którzy mu podlegali, nadawali imiona dopiero co obrzezanym. Podobnie teraz chrześcijanie, idąc za tym samym przykładem, zwykli w czasie chrztu ochrzczonym nadawać imiona, aby to, co poleca obrzęd religijny, zgadzało się z prawzorem.

${ }^{18}$ Przekładu dokonano na podstawie wydania J.P. Migne, PL 110, 17-18; tłum. ks. Jarosław Adamiak. 
Co jednak owo wynikające $\mathrm{z}$ Prawa obrzezanie oznacza, pokazuje prorok, gdy mówi: Obrzezajcie jednak wasze serca, a nie ciała (por. Pwt 10, 16). Takie obrzezanie serca poleca nam Apostoł: „Porzućcie starego człowieka wraz z jego uczynkami, bo on staje się nieprawy na skutek złudnych pragnień, przyobleczcie zaś nowego człowieka, który z dnia na dzień się odnawia według obrazu Tego, który go stworzył" (Ef 4, 22-24). Czynami bowiem starego, to jest grzesznego człowieka, są: pycha, chciwość, nierząd, czyny nieczyste, swawola, bałwochwalstwo, czary, przejawy wrogości, spory, porywy gniewu, wściekłości, kłótnie, niezgoda, odstępstwo, zawiść, zabójstwo, kradzież, pijaństwo, obżarstwo i tym podobne: a wymieniam je wobec was, ponieważ kto tak postępuje, królestwa Bożego nie posiądzie (por. Ga 5, 19-21). Natomiast uczynki człowieka nowego, to jest sprawiedliwego, to: bezinteresowna miłość, radość, pokój, wielkoduszność, dobroć, uprzejmość, wierność, skromność, cierpliwość, opanowanie, pokora, trzeźwość i tym podobne. Kto zatem nimi się kieruje, ten podoba się Bogu i znajduje uznanie u ludzi. O to więc proszę, bracia, abyście w święto Obrzezania obrzezali siebie samych, przez to zaś zasłużycie na to, by się stać członkami tego, który dziś wobec nas zechciał poddać się obrzezaniu i przyjąć przepowiedziane wcześniej przez usta anioła imię Jezusa Chrystusa, naszego Zbawiciela, który z Ojcem i Duchem Świętym żyje i króluje, Bóg przez wszystkie i nieskończone wieki. Amen.

\section{Homilia VII: Na Epifanię Pańskq ${ }^{19}$}

Tak niedawno, bracia najmilsi, uroczyście obchodziliśmy dzień, w którym Bóg przyjął na siebie człowieczeństwo wraz z jego słabością, a nieco później [wspominaliśmy], iż zechciał zgodnie z Prawem poddać się obrzezaniu. Dziś natomiast świętujemy i służbą Bożą czcimy to, że On sam oznajmił swą potęgą, iż jest w swym człowieczeństwie Bogiem. Uroczystość tę określa się także greckim słowem Epifania, co możemy tłumaczyć jako „Objawienie”, a to $\mathrm{z}$ tego powodu, że $\mathrm{w}$ tym dniu wzejście na niebie gwiazdy obwieściło Boską nowinę, Magowie zaś po usilnych poszukiwaniach dotarli do żłóbka. Dalej w wodach Jordanu Zbawiciel przez swój chrzest uświęcił samą wodę dla odnowienia rodzaju ludzkiego, a przez zstąpienie Ducha Świętego i słyszany przez wszystkich głos Ojca dał się poznać jako prawdziwy Bóg. W Kanie Galilejskiej w czasie uczty weselnej zamienił wodę w wino i, jak zaświadcza Ewangelia, przez początek znaków objawił swoją chwałę, a uczniowie Jego w Niego uwierzyli. Wreszcie pięcioma chlebami nasycił pięć tysięcy ludzi, a wyznanie wiary ludu ogłosiło: „Ten jest rzeczywiście Prorokiem, który ma przyjść na świat" (J 6, 14). Gdy zaś usłyszano wszystkie te tajemnice, jak nam przekazali święci ojcowie, dzisiejszy dzień wyróżnił się czcigodnościa,

${ }^{19}$ Przekładu dokonano na podstawie wydania J.P. Migne, PL 110, 18-19; thum. ks. Jarosław Adamiak. 
skoro tak wielkimi świadectwami objawił się dziś Chrystus, Bóg w człowieku. Wszystkie te sprawy dotyczą godnych czci tajemnic, lecz mają także i ten wpływ na nas, że umacniają nas w wierze katolickiej, w tej mianowicie, która służy z miłością, a nas uczy, jak żyć, ażeby podobać się we wszystkim naszemu Stwórcy.

Chciałbym jednak, bracia powiedzieć wam jeszcze coś o owych słynnych trzech darach, które w dniu dzisiejszym Magowie ofiarowali naszemu Odkupicielowi. A ofiarowali $\mathrm{Mu}$, jak przed chwilą słyszeliście, gdy odczytywano Ewangelię, złoto, kadzidło i mirrę. Jednakże w owej troistości darów zawiera się potrójne znaczenie: w kadzidle wyrazili chwałę Boga, w złocie godność królewska, mirra [to zapowiedź] pogrzebania ciała. Ofiarujmy więc i my, najmilsi bracia, szczere i święte dary naszemu Bogu, to jest wiarę, nadzieję i miłość. Ofiarujmy złoto mądrości, kadzidło oddanej modlitwy, mirrę w umartwianiu ciała. Ofiarujmy powściagliwość cielesna, szlachetność w mowie, rzetelność w uczynkach. Ofiarujmy czystość duszy, niewinność ciała i czujność w pokorze. Ofiarujmy współczucie, wielkoduszność i opanowanie. Ofiarujmy życzliwość, roztropność i miłosierdzie. Oto są bowiem dary miłe Bogu, ofiary przyjemne, które jemu składamy, a przecież przynoszą one pożytek składającym: żadnej rzeczy bowiem, żadnego dobrodziejstwa Mu nie brakuje, ale najlepszym dlań darem jest to, by miał okazję do obdarowania kogoś. Niczego więcej od nas nie żąda, niczego więcej nie oczekuje, jak tylko naszego zbawienia: uznaje On bowiem, że dajemy Mu wszystko, jeśli do tego stopnia niczego nie mamy, iż On wszystko nam daje. O spełnienie tego winniśmy Go prosić, aby Jego miłosierdzie nie tyle nas wyprzedziło, lecz podążało za nami przez wszystkie dni naszego życia, abyśmy zamieszkali w domu Pana po najdłuższe dni, co też niech raczy sprawić On sam, który żyje i króluje na wieki wieków. Amen.

\section{Homilia VIII: Na Hypapante, czyli na Ofiarowanie Pana w świq̨yni ${ }^{20}$}

Dopiero co nabożnie odczytany fragment Ewangelii, bracia najmilsi, przedstawia świętą i godną najwyższego uszanowania dzisiejszą uroczystość, w której oddajemy należną cześć, wspominając czterdziesty dzień od Narodzenia Pańskiego i największe uniżenie się tegoż Pana i Zbawiciela naszego oraz jego nieskalanej Rodzicielki. Oto widzimy tych, którzy w niczym nie są winni wobec Prawa, jak we wszystkim mu się poddają, wypełniając jego przepisy. $\mathrm{Z}$ tego powodu wspomina [Ewangelia], że właśnie wypełnili nakaz oczyszczenia w odpowiednim czasie według Prawa Mojżeszowego. Nakazuje ono bowiem (por. Kpł 12, 2), aby kobieta, która poczęła i urodziła syna, przez siedem dni była nieczysta, a w dniu ósmym obrzezała dziecię i nadała mu imię. Następnie jeszcze przez trzydzieści trzy dni miała się powstrzymywać

${ }^{20}$ Przekładu dokonano na podstawie wydania J.P. Migne, PL 110, 19-20; tłum. ks. Jarosław Adamiak. 
od wstępowania do świątyni i do łoża małżeńskiego, aż w czterdziestym dniu od porodu przyniesie syna wraz z ofiarami do świątyni Pana. [Prawo stanowiło, że] wszystko, co pierworodne płci męskiej, poświęcone jest Panu i dlatego wszystko, co czyste należy ofiarować Bogu, nieczyste zaś wymienić na czyste, lub zabić; natomiast pierworodnego syna należało wykupić pięcioma syklami srebra; pozostałe [przepisy] szczegółowo przedstawia Księga Kapłańska. Skoro zatem Prawo nakazuje, ażeby kobieta, która poczęła i urodziła, uznawana była za nieczystą i aby po dłuższym czasie wraz z potomstwem, które wydała, została poddana oczyszczeniu, to jasno stąd widać, iż Tej, która jako dziewica poczęła bez udziału męża, wraz z Synem, który się Jej urodził, [Prawo] ani nie określa jako nieczystej, ani nie nakazuje, by była oczyszczona przez złożenie ofiary. Lecz jak Pan i Zbawiciel nasz, który za zrządzeniem Opatrzności ustanowił Prawo, ukazując się jako człowiek zechciał się Prawu poddać, ażeby odkupić tych, którzy byli pod władzą Prawa, byśmy mogli dostąpić przybrania za synów, podobnie i Jego błogosławiona Rodzicielka dla ukazania przykładu pokory nie odstapiła od poddania się przepisom Prawa. I jak napisane jest w Prawie Pana, złożyli na ofiarę parę synogarlic, albo dwie młode gołębice. Była to ofiara przynależna ubogim, nakazał bowiem Pan w Prawie, aby ci, którzy są w stanie, ofiarowali za syna lub córkę baranka, ale jednocześnie synogarlicę lub gołębicę. Kto tego uczynić nie mógł, ofiarował właśnie synogarlice lub dwie młode gołębice. Tak oto nasz Odkupiciel nade wszystko pamiętając o naszym zbawieniu, choć był Bogiem zechciał stać się człowiekiem, ale także, choć był wszechpotężny, stał się ubogim, aby nas uczynić bogaczami przez swe ubóstwo, a przez swoje człowieczeństwo przybranymi synami Boga.

Jednakże, gdy dziś uroczyście obchodzimy wkroczenie Zbawiciela i jego Rodzicielki do świątyni, naśladujmy też osoby, które wyszły mu tam naprzeciw, jak przed chwilą usłyszeliśmy w Ewangelii. Oto święty Symeon, przywiedziony do świątyni przez Ducha Świętego wziął w ramiona Dziecię i błogosławił Pana. Oto Anna, pobożna niewiasta i wdowa, zbliżywszy się, w tej samej chwili oddawała cześć Bogu i mówiła o Nim wszystkim, którzy wyczekiwali odkupienia Izraela. Także i my wyjdźmy na spotkanie Jezusowi i z wielką radością weźmy Go w ramiona przez nasze dobre czyny. Oddawajmy cześć Jego wielkiemu Imieniu, opowiadajmy o Jego miłosierdziu i o cudach, jakich w nas dokonał wszystkim, którzy oczekują odkupienia Jeruzalem i pociechy Izraela. Tę właśnie pociechę przewidział w Duchu psalmista, mówiąc: „Pocieszysz nas, Panie, radością przed Twoim obliczem, szczęściem bez miary po Twojej prawicy" (Ps 16, 11). Ofiarujmy Mu prostoduszność, którą oznacza gołębica; ofiarujmy czystość ciała wyrażoną przez synogarlicę, ofiarujmy Mu wraz ze skromnością obyczajów skruszone serce, co oznacza śpiew obojga staruszków. Pismo mówi bowiem: „Ofiarą dla Pana duch skruszony, skruszonym i ukorzonym sercem Bóg nie gardzi” (Ps 51, 19). Oto są podarunki, oto ofiary, które cieszą i radują Chrystusa. Rzeczy stare przeminęły, a oto wszystko stało się nowym. Tak zatem sami staniemy się miłą ofiarą dla 
Boga, jeśli obmyjemy nasze poprzednie grzechy łzami i dziełami miłosierdzia i gdy przynagleni pragnieniem niebiańskiego szczęścia żyjąc sprawiedliwie w codziennej modlitwie do Boga mówić będziemy: ,Spragniona jest ma dusza Boga żywego, kiedyż przyjdę i ukażę się przed obliczem Boga?” (Ps 41, 3). [Staniemy się miłą Bogu ofiara] gdy nasze pragnienie wypełni Ten, który ze względu na nas przyjął ciało i siebie samego wydał, aby nas odkupić własną krwią, Chrystus, nasz Zbawiciel, który żyje i króluje z Bogiem Ojcem w jedności Ducha Świętego przez wszystkie wieki wieków. Amen.

\section{Homilia XIV: Na Dzień Palm ${ }^{21}$}

Rzeczą bardzo stosowną wydaje się, bracia najdrożsi, wyłożenie wam krótko podczas tej Mszy świętej tego, na co wskazuje dzisiejsza uroczystość. Jedni z was znają powód dzisiejszego święta; inni zaś, dlatego że obrzęd odbywa się na zewnątrz, zupełnie nie rozumieją go wewnętrznie.

Ewangelia święta opowiada, że nasz Odkupiciel, gdy zbliżał się czas Jego męki, sześć dni wcześniej wyruszając do Jerozolimy, kazał swoim uczniom, aby przyprowadzili Mu osiołka. Gdy go przyprowadzono, apostołowie włożyli na niego swoje szaty i posadzili na nim Jezusa. Bardzo wielki zaś tłum słał swoje szaty na drodze, inni zaś, ścinając gałązki z drzew, tak samo ścielili drogę, aby ten osioł mógł iść bez szwanku. Ci zaś, którzy szli na przedzie i ci, którzy szli za nimi, wołali: „Hosanna Synowi Dawidowemu, błogosławiony, który przychodzi w imię Pańskie, Król Izraela, Hosanna na wysokości” (Mt 21, 9). Ponieważ Pan Jezus w takim triumfie wszedł do Jerozolimy, w dzisiejszym zgromadzeniu na pamiątkę naszego Odkupiciela obchodziliśmy to, co się historycznie wydarzyło, uważając, że właściwe będzie wyjaśnić wam, co to znaczy duchowo.

Ten osioł, na którym usiadł Pan, oznacza lud pogański, z którego i my jesteśmy - lud, który przez przepowiadanie Ewangelii apostołowie uwalniając z więzów nieprzyjaciela, to jest diabła, przyprowadzili do Chrystusa. Włożyli na osła swoje szaty, to znaczy, że okryli nagość jego grzechów przykazaniami Pańskimi i łaską duchową. Posadzili Pana, to znaczy sprawili, że mieszka i rozkazuje. Bardzo wielki zaś tłum, który słał swoje szaty na drodze, oznacza męczenników, którzy wydali swe ciała na śmierć za Chrystusa i dali przykład nam, którzy jesteśmy zwierzętami jucznymi Pana, abyśmy za wiarę Chrystusową znosili cierpliwie wszelkie przeciwności. Ci zaś, którzy brali gałązki z drzew owocowych, to jest święte świadectwa od proroków, nam dzisiaj ścielą drogę, to znaczy porządkują naszą drogę, abyśmy bez szkody wyrządzanej przez grzechy, pod kierunkiem zasiadającego Pana, mogli wejść do miasta świętego, to jest Jeruzalem niebieskiego. Ci zaś, którzy szli na przedzie i ci, którzy szli za nimi i wołali: „Hosanna synowi Dawidowemu” (Mt 21, 9)

\footnotetext{
${ }^{21}$ Przekładu dokonano na podstawie wydania J.P. Migne, PL 110, 29-30; thum. ks. Tadeusz Gacia.
} 
oznaczają tych świętych, którzy poprzedzili cieleśnie przyjście Pana i tych, którzy poszli za Nim po Jego wniebowstąpieniu oraz zgodnie obwieszczali Jego chwałę i prawdziwie głosili Jego majestat. Co prorocy i patriarchowie przepowiedzieli o Nim, że się to stanie w przyszłości, apostołowie i ewangeliści opowiadali, że już się to wypełniło.

Zastanawiając się przeto nad tym, bracia najdrożsi, rozważmy dobrze miłosierdzie naszego Stwórcy, który najpierw stworzył nas jako dobrych i nieśmiertelnych, a gdy po sprzeniewierzeniu się i upadku staliśmy się ułomni i śmiertelni, przez Jednorodzonego Syna swojego wyzwolił nas spod władzy diabła i z więzów grzechu.

Chciejmy upokorzyć się pod takim Panem, który zasiada, bo Jego jarzmo jest słodkie, a Jego brzemię jest lekkie (por. Mt 11, 30). Starajmy się ile tylko możemy o to, abyśmy niosąc Go, wystrzegali się szkód grzechów. Mamy drogę przygotowana, bo wszelkie Pismo przez Boga natchnione i dane, poucza nas i wskazuje, aby prostą drogą zdążać do naszej ojczyzny i ze szlachetnym zapałem przez wiarę, nadzieję i miłości przyjść do naszego Stworzyciela.

Już zbliża się święty dzień Paschy. Ten tydzień, bracia najdrożsi, bardziej niż inne tygodnie roku, jest pełen niebieskich tajemnic. W tym tygodniu nasz Zbawiciel codziennie, aż do czasu swej męki, uczył w świątyni. W tym tygodniu, to jest w czwartek tego tygodnia, podczas mistycznej wieczerzy przekazał sam najpierw swoim uczniom tajemnice Ciała i Krwi swojej, kiedy także umył im nogi; w piątek także dopełnił tajemnice swego krzyża i męki, w sobotę zaś spoczywał w grobie. My więc, którzy podczas tego wielkiego postu aż do teraz szlachetnie się trudziliśmy, starajmy się wytrwać w tym aż do jego końca. My zaś, którzy dotąd byliśmy gnuśni, przynajmniej w ciągu tych siedmiu dnia starajmy się przez posty i hojne jałmużny, przez czuwania i modlitwę, przez łzy i skruchę serca znaleźć miłosierdzie u naszego Odkupiciela, aby w Paschę, kiedy przystąpimy do świętego stołu Pańskiego, Jego oczy nie zatrzymały się z gniew na nikim z nas, by przypadkiem nie powiedział do kogoś: „Przyjacielu, po co przyszedłeś, jak tu wszedłeś nie mając szaty weselnej?” (Mt 22, 12). Niech pozwoli nam uniknąć swego gniewu, i owszem, znaleźć swoją łaskę, Ten, który nas odkupił, Chrystus, nasz Zbawiciel, który z Ojcem i Duchem Świętym żyje i króluje, Bóg przez wszystkie wieki wieków. Amen.

\section{Homilia XV: Podczas Wieczerzy Pańskiej ${ }^{22}$}

Nie wolno opuścić, bracia najdrożsi, nazwani synami Bożymi, wygłoszenia jakiegoś słowa zachęty w związku z tym świętym i drogim dniem, jakim jest uroczystość dzisiejsza, którą świętuje i czci wszystek Kościół Boży rozproszony po całym świecie. Tak jak ciało nie może żyć bez codziennego pokarmu, tak i dusza, która jest o wiele cenniejsza, jeśli chodzi o jej pochodzenie, [nie może

\footnotetext{
${ }^{22}$ Przekładu dokonano na podstawie wydania J.P. Migne, PL 110, 30-33; thum. ks. Tadeusz Gacia.
} 
żyć] bez słowa Bożego. Albowiem jak ciało wraca do ziemi, z której wzięło początek, tak dusza do nieba, jeśli zawsze żywi się i pokrzepia Bożym słowem, które jest jej pokarmem. To ono swą słodyczą przewyższa miód, jak świadczy prorok Dawid: „Jak słodkie są memu podniebieniu słowa Twoje, Panie, ponad miód ustom moim" (Ps 118, 103). Każdy więc człowiek powinien niewątpliwie wiedzieć, że Syn Boży, tak jak narodził się na tym świecie, tak też opuścił świat, jak to zaświadcza ewangelista Jan w tym czytaniu ewangelicznym, które właśnie usłyszeliście: „Przed dniem świątecznym Paschy Jezus wiedział, że nadeszła Jego godzina, aby przeszedł z tego świata do Ojca" (J 13, 1). Syn Boży bowiem, od którego pochodzi wszelka cześć i potęga, dla nas został pozbawiony czci, ubiczowany, spoliczkowany, opluty, związany, nosił cierniową koronę, został sprzedany i tak w końcu przez mękę krzyżową przyjął śmierć, powstał z martwych, wstapił do swojego Ojca w niebie, skąd zstapił. Tak i my musimy do naszego Ojca, ponieważ tym właśnie jest Chrystus, przechodzić z tego świata, odpuszczać nieprawości i czynić sprawiedliwość, dawać hojnie dobra doczesne przez wzgląd na wieczne, porzucić diabła i jego złe czyny oraz czynić i kochać to, co się Bogu podoba. Miłować Boga z całego serca i z całej duszy, naszego bliźniego, którym jest każdy chrześcijanin, jak siebie samych; unikać kłamstw, pychy, zabójstw, cudzołóstwa, kradzieży i tym podobnych. Jeśli te dobra czynimy i unikamy zła, o którym powiedziałem, naśladujemy i my Syna Bożego, podobnie wstępując do naszego Ojca, który jest w niebie, który wszystkim rządzi i wszystko ma. Następują słowa: „Umiłowawszy swoich, którzy byli na świecie, do końca ich umiłował" (J 13, 1). Tak bardzo Pan umiłował swoich, którzy byli na tym świecie, że nawet samego siebie wydał za nich na śmierć, bo „większej nad tę miłość nikt nie mam, żeby kto życie swe oddał za przyjaciół swoich" (J 15, 13).

Gdy wieczerza została przygotowana i zgromadzili się uczniowie z Nauczycielem, natychmiast diabeł skłonił serce Judasza, aby swego Nauczyciela i Pana naszego wydał Żydom. Tak jak diabeł podsuwa złe myśli złym i niegodziwym, a takim był Judasz, tak Duch Święty zaszczepia dobrym i sprawiedliwym pobożne i prawe myśli. Tak czynił zawsze swym uczniom, posyłając ich przed królów i namiestników. Powiedział: „Gdy staniecie przed nimi, nie obmyślajcie, jak i co macie mówić, ponieważ dane wam będzie w owej godzinie, co macie mówić" (Mt 10, 19), Ten, który wydał Boga, zdrajca Judasz przyszedł na ucztę bez wiary, bo gdyby miał wiarę naprawdę, nigdy nie wydałby Go bezbożnym Żydom. Wiedząc zaś Jezus, że Bóg Ojciec wszystko dał mu we władzę, a nawet swego zdrajcę, i wiedząc, co powinien czynić dla swoich przyjaciół, i że od Boga Ojca na ten świat przyszedł, jednak nie opuszczając Go bóstwem, i że na nowo do Niego ma wrócić, nigdy nam nie zabierając swej łaski, wstaje od wieczerzy i składa szaty. I zaraz zaczyna umywać nogi uczniów, wypełniając powinność sługi, chociaż był Stwórca wszystkiego, tego, co w niebie, na ziemi i pod ziemią. Najpierw podchodzi do Piotra, ponieważ był najwyższym i pierwszym z apostołów. Słusznie, bo 
dał mu klucze królestwa niebieskiego, aby cokolwiek rozwiąże na ziemi, było rozwiązane w niebie. Wtedy bardzo się święty Piotr zawstydził tego, że Syn Boży, Stwórca Jego i wszechświata, musiał myć nogi swego sługi i powiedział: „Panie, Ty nigdy nie będziesz mi nóg umywał” (J 13, 8). Bo Ty jesteś Panem, a ja sługa; Ty Bogiem, a ja człowiekiem; Ty Odkupicielem, ja grzesznikiem. Odpowiedział mu Jezus: „Co Ja czynię, ty teraz tego nie wiesz, ale dowiesz się potem" (J 13, 7); to tak jakby powiedział: Tajemnicy tego wydarzenia jeszcze nie rozumiesz, ale potem będziesz mógł zrozumieć, bo ,jeśli ci nóg nie umyję, nie będziesz miał cząstki ze Mną" (J 13, 8). Piotr zaś po raz drugi zakazał $\mathrm{Mu}$, mówiąc: nie będziesz mi nigdy nóg umywał; lecz za trzecim razem, przeraził się słowem Pana, bo powiedział: „Panie, nie tylko nogi, ale i ręce i głowę" (J 13, 9); jeśli grozisz więc, że miałbym nie mieć żadnej wspólnoty z Tobą ze względu na umycie nóg, teraz po to, aby mieć jakąś część wspólnoty z Toba, nie zabraniam Ci obmyć żadnej części mojego ciała. Odpowiedział Jezus: „Kto się wykapał, potrzebuje tylko nogi sobie umyć, lecz cały jest czysty" (J 13, 10). Znaczyło to zaś: Każdy więc kto przyszedł do świętego chrztu i przyjął go w imię Ojca, i Syna, i Ducha Świętego, od razu cały jest czysty, tak na duszy jak i na ciele, bo w obmyciu chrzcielnym odpuszczane są i zmazywane grzechy ludzi, gdyż zanim zostaną ochrzczeni, nazywani są synami diabła, potem zaś synami Bożymi. To zaznaczył Pan, gdy mówi: „Kto się wykapał, potrzebuje tylko nogi sobie umyć, lecz cały jest czysty" (J 13, 10). Bo jak stopy, które depcą ziemię, nie mogą nie być w ogóle pobrudzone, tak nikt w tym świecie i w tym ciele śmiertelnym nie może żyć bez grzechu, jak świadczy święty Jan: „Jeśli byśmy powiedzieli, że grzechu nie mamy, siebie samych zwodzimy i prawdy w nas nie ma" (1J 1, 8). Gdy zaś człowiek po chrzcie zabrudzi się przez jakiś zły czyn, musi powtórnie oczyścić się tą sama łaską Bożej dobroci, to jest dając pieniądze, jałmużnę, modlitwę, opłakiwać nieprawość, którą popełnił, szukać dobra, które grzesząc utracił. Duchowo zaś Pan codziennie myje nasze nogi, gdy prosi Boga Ojca za nami. Podobnie my sami codziennie powinniśmy obmywać nasze nogi, wyznając w sercu grzechy przy odmawianiu Modlitwy Pańskiej: „Odpuść nam nasze winy, jako i my odpuszczamy naszym winowajcom" (Mt 6,12).

Kiedy Syn Boży, upokarzając się, wypełnił wszystko, co wam wyliczyłem, powiedział do nich: „Wiecie, co wam uczyniłem. Jeśli Ja, Pan i Nauczyciel, umyłem nogi wasze, i wy powinniście jeden drugiemu nogi umywać, abyście jak Ja wam uczyłem, tak i wy czynili" (J 13, 12-14). To tak jakby powiedział: Jeśli Ja, Bóg i Pan, odpuściłem wam wasze grzechy, o tyle bardziej i wy powinniście jeden drugiemu darować grzechy. To zaś, że ewangelista mówi, iż Pan wstał od wieczerzy, znaczy, że Syn Boży zstapił z niebieskiego tronu Ojca na ziemię, przyjmując na siebie nasze ciało. Składa swoje szaty, to znaczy, że uniżył się i był posłuszny Bogu Ojcu aż do śmierci. Przepasał się prześcieradłem, ponieważ przyjął postać sługi. Nalał wody do miednicy, kiedy wylał krew swoją na ziemię, aby oczyścić stopy wierzących w Niego, 
zabrudzone ziemskimi grzechami. Wytarł stopy prześcieradłem, kiedy umierając ze względu na nas, swym własnym ludzkim ciałem oczyścił zbrodnie naszych grzechów. Umycie nóg uczniów oznaczało, że przez wylanie swej krwi dopełnił oczyszczenia naszego odkupienia. To zaś, że ewangelista mówi, iż przywdział swoje szaty, oznacza, że trzeciego dnia powstał z grobu w tym samym ciele, w którym umarł, znów został przyodziany i stał się nieśmiertelny. To zaś, że czytanie ewangeliczne mówi, iż Jezus znowu zasiadł, oznacza, że ponownie wstąpił do Ojca swojego, skąd zstąpił, siedzi po prawicy Bożej, w majestacie Ojcowskiego Bóstwa, i stamtąd ponownie przyjdzie sądzić żywych i umarłych. Obyście zasłużyli na to, by w czasie przyszłego sądu spotkać Go jako Boga jako łagodnego i łaskawego wraz z innymi, którzy sprawiedliwie sądzą okrąg ziemi i abyście z Nim mogli królować w wiekuistej szczęśliwości na wieki wieków. Amen.

\section{Homilia XVI: Na Wielka Sobote $e^{23}$}

Oto, najdrożsi bracia, nadeszła długo oczekiwana uroczystość, w czasie której nasz Zbawiciel, związawszy władcę ciemności i złamawszy bramy śmierci, zabrał łup świętych dusz i triumfując nad piekłem, zmartwychwstał w chwale. W tę noc, jak właśnie usłyszeliśmy z czytania ewangelicznego, gdy wstawał z martwych nasz Odkupiciel, stało się wielkie trzęsienie ziemi. Anioł Pański zstąpił z nieba i zbliżywszy się, odsunął kamień od wejście do grobowca i usiadł na nim. Żydzi, przez swą bardzo wielką przewrotność, zapieczętowali grobowiec i postawili przy nim straże. Wygląd anioła zaś był jak błyskawica, a jego szaty jak śnieg. Ze strachu przed nim zadrżeli strażnicy i stali się jak umarli. Do kobiet również, które zapalone miłością do Zbawiciela, przyszły do grobu, ten sam anioł powiedział: „Nie bójcie się wy, gdyż wiem, że szukacie Jezusa, który był ukrzyżowany. Nie ma Go tu, albowiem powstał jak powiedział. Chodźcie, a oglądajcie miejsce, gdzie był położony Pan. A prędko idąc, powiedzcie uczniom Jego, że powstał i oto poprzedza was do Galilei, tam Go zobaczycie. Oto wam zapowiedziałem" (Mt 28, 5-7).

Dla nas bowiem i ze względu na nas Chrystus się narodził, cierpiał, zmartwychwstał, abyśmy my w życiu przez Niego się odrodzili. Wszystko bowiem przez Niego w tę noc zostało odbudowane. W tę właśnie noc Chrystus zmartwychwstał jako pierwociny tych, którzy zasnęli. W tę noc nasza niewola się kończy; życie, stracone w Adamie, zostaje odbudowane. W tę noc starożytny prarodzic jako pielgrzym wraca do rajskiej ojczyzny, bo Chrystus odpędził cherubów. Od tej bowiem nocy zmartwychwstania Pańskiego raj stoi otworem, przed nikim nie jest zamknięty, chyba, że ktoś sam go sobie zamyka; przed nikim nie jest otwarty, otwiera go tylko Chrystus. Po to bowiem dziś Pan zmartwychwstał, aby pokazać nam obraz przyszłego zmartwychwstania.

\footnotetext{
${ }^{23}$ Przekładu dokonano na podstawie wydania J.P. Migne, PL 110, 33-34; thum. ks. Tadeusz Gacia.
} 
I dlatego dziś lud Boży, powstając przez życiodajne obmycie, na podobieństwo zmartwychwstania, oświetla nasz Kościół śnieżnobiałym blaskiem.

Powinniśmy składać dzięki naszemu Bogu, najdrożsi, za to, że obchodząc świętą uroczystość paschalną, już widzimy w odrodzonych formę przyszłego zmartwychwstania. O tym przeto przypominam wam, najmilsi bracia, że ilekroć przychodzi uroczystość paschalna, wszyscy - mężczyźni i kobiety - którzy przyjęli duchowo dzieci ze świętego źródła, mają wiedzieć, że są dla ich poręczycielami wiary u Boga. Dlatego niech zawsze z prawdziwą miłością o nich się troszcza, niech ich upominają i karca, niech napominają, aby przestrzegali przyzwoitości, aby zachowywali dziewictwo aż do ślubu, aby hamowali język od przekleństwa i krzywoprzysięstwa, aby z ich ust nie wychodziły sprośne i rozpustne piosenki, aby się nie pysznili, nie nienawidzili, aby nie chowali w sercu złości lub nienawiści, aby nie zasięgali wróżb, nie zawieszali na sobie lub na innych amuletów i zabobonnych oznak diabelskich, unikali czarowników jako sług diabła, trzymali się wiary katolickiej, częściej chodzili do kościoła, gardzili wielomówstwem, a słuchali uważniej czytań Bożych, przyjmowali wędrowców i - zgodnie z tym, co jest nakazane w Piśmie Świętym - myli nogi przybyszom, sami zachowywali pokój i starali się żyjących w niezgodzie doprowadzić na nowo do zgody, kapłanom i rodzicom okazywali cześć i prawdziwą miłość. O tym wszystkim więc i o tym podobnych wypada przypominać swoim synom i córkom, abyście wraz z nimi doszli pomyślnie do szczęśliwości wiecznej.

Niech nikt się nie odgradza od innych, bracia najdrożsi, niech żaden człowiek nie żyje tylko dla siebie, lecz - jak często mówiłem - jeśli ktoś przez przykład świętego życia zbuduje wielu innych, z nimi wszystkimi i za to, co uczynił, otrzyma jako nagrodę błogosławioną zapłatę. A ilu ludziom ktoś da przykład złego życia, to chociażby oni za nim nie poszli, niech wie, że z tego wszystkiego będzie zdawał rachunek, bo dał im sposobność do śmierci i zgotował powód zguby. I dlatego, jak już wyżej powiedziałem, przy pomocy Pana, o ile tylko możemy, powinniśmy dawać naszych neofitom przykład dobrego życia, abyśmy nie otrzymali za ich zepsucie kary, lecz z łaski Pana zasłużyli na to, by dzięki ich zbudowaniu dojść do przebaczenia naszych win i posiąść radości wieczne. Amen.

\section{Homilia XVII: Na Niedziele Wielkanocna ${ }^{24}$}

Paschą nasza, najmilsi, jest Chrystusowe zmartwychwstanie. Słowo „Pascha” tłumaczy się jako „przejście”, to znaczy przejście ze śmierci do życia, od męki do chwały, z piekła do raju. Dlatego że Chrystus umarł, nasza śmierć została zniszczona, a dlatego że zmartwychwstał, dał nam możliwość zmartwychwstania i sprawił, że przechodzimy z niewiary do wiary katolickiej, $\mathrm{z}$ bałwochwalstwa do czci jedynego Boga, z grzechu do sprawiedliwości,

\footnotetext{
${ }^{24}$ Przekładu dokonano na podstawie wydania J.P. Migne, PL 110, 34-35; thum. ks. Tadeusz Gacia.
} 
z błędu do prawdy, z niezgody do pokoju, z bycia sługami nieużytecznymi i z oddania się na służbę diabłu do grona synów Bożych, z wygnania do ojczyzny, od kary do zwycięskiego wieńca. I dlatego, najmilsi, pascha Chrystusa jest królestwem niebieskim, zbawieniem świata, śmiercią piekła, chwała niebian, życiem wierzących, zmartwychwstaniem umarłych, dowodem zmiłowania Bożego, ceną odkupienia ludzkiego, a władza śmierci została usunięta.

Ta uroczystość, uświęcona przez Boże misterium, głosem aniołów wskazuje na moc zmartwychwstania Pańskiego, obwieszcza ją narodom, w sercach wierzących pomnaża dobro. To jest przeto ten dzień, o którym śpiewał kiedyś psalmista: „Oto dzień, który uczynił Pan, radujmy się i weselmy w nim” (Ps 118, 24). Wznioślejszy dla wszystkich, jaśniejszy dla wszystkich, dzień, w którym Pan zmartwychwstał, w którym nabył sobie nowy lud, jak tam widzicie, przez odrodzenie duchowe; w którym serce każdego z osobna napełnił radością i weselem. Ten więc dzień zmartwychwstania Chrystusa jest dla umarłych życiem, dla grzeszników przebaczeniem, dla świętych chwałą. Jak więc Maryja Dziewica, Matka Pana, zajmuje pierwsze miejsce wśród wszystkich niewiast, tak i na ziemi dzień ten jest głową wszystkich dni. I jak w Piśmie Świętym czytamy o Świętym świętych i o Pieśni nad pieśniami, tak i ten dzień słusznie nazywamy uroczystością nad uroczystościami. Ów ognisty miecz i wrota do raju, których nikt nie mógł przełamać, teraz Chrystus wraz z łotrem otworzył. Brama raju, która przed męką Pańską dla nikogo nie została otwarta, od tego czasu, gdy Pan został umęczony aż do dzisiejszego dnia i zamknięta jest, i otwarta. Zamknięta dla grzeszników i dla niewiernych, otwarta dla sprawiedliwych i dla wierzących. Przez nią wszedł Piotr, przez nią wszedł także Paweł, przez nią weszli wszyscy męczennicy, przez nią codziennie wchodzą dusze sprawiedliwych z całego świata. Dwie są bowiem bramy - brama raju i brama Kościoła. Przez bramę raju wchodzimy najpierw - to znaczy przez wiarę i chrzest, ponieważ - jeśli wytrwamy wiernie, czyniąc dobrze - po zakończeniu życia wejdziemy w bramę raju.

Kościół święty jest również bez wątpienia domem Bożym i tak powinniśmy żyć, by nas nie wyrzucono z tego domu; gdy zostaniemy wyrzuceni na zewnątrz, pożrą nas dzikie zwierzęta, to znaczy złe duchy, o których mówi prorok: „Nie wydawaj, Panie, zwierzętom, dusz wyznających Ciebie” (Ps 74, 19). Wytrwale więc żyjmy w tym Kościele, który jest naszą Matką, abyśmy mogli dojść do królestwa Ojca wiecznego, dla którego ta Matka zrodziła nas jako przybrane dzieci. Świętujmy tę najświętszą uroczystość tak, jak nas pouczył apostoł Paweł: „Nie na starym kwasie ani w kwasie złości i przewrotności” (1Kor 5,8), to jest nie w zgorzknieniu ludzkiej złości, lecz w czystości świętości Bożej, którą jest wstrzemięźliwość, pokora, dobroć, miłosierdzie, uprzejmość, sprawiedliwość, łagodność, cierpliwość, prawda, pokój, życzliwość. To jest ciasto świętości chrześcijańskiej, którą niszczy kwas złości ludzkiej, to jest żądza, pycha, zawiść, niegodziwość, chciwość, nieumiarkowanie, kłamstwo, niezgoda, nienawiść, próżna chwała, okrutność i niesprawiedliwość. Niechaj te 
wszystkie rodzaje zepsucia oddali od nas i niechaj strzeże w nas czystości swej prawdy sam hojny Dawca wszelkich dóbr, który podarował nam tę najświętszą uroczystość - Jezus Chrystus, nasz Zbawiciel, który żyje i króluje z Bogiem Ojcem w jedności Ducha Świętego, Bóg przez wszystkie wieki wieków.

\section{Homilia XVIII: Na Oktawe Wielkanocy lub pozostate niedziele po Wielkanocy ${ }^{25}$}

Najdrożsi bracia! Oto nastały dni, które Kościół katolicki na całym świecie obchodzi ze względu na niezwykłe znaczenie Niedzieli Zmartwychwstania, ponieważ nasz Zbawiciel po swoim Zmartwychwstaniu, jak to poświadcza św. Łukasz, przez czterdzieści dni objawiał się swoim uczniom przez liczne znaki i ukazywał im prawdziwość swojego Zmartwychwstania. Dlatego też, kierując się tradycją przekazaną przez świętych ojców, powinniśmy te dni uważać za świąteczne i z radością w duszy świętować chwałę Zmartwychwstania Pańskiego. W tym czasie również nie obowiązuje post, chociaż w każdym czasie powinniśmy zachowywać umiar. Zatem czas Wielkiego Postu (Czterdziestnicy), który przeżywaliśmy przed Wielkanocą, zachowując post i umartwienie ciała, jest odbiciem doczesności, w której powinniśmy współuczestniczyć w mękach Chrystusa przez umartwianie ciała. Ten zaś czas, który upływa od Wielkanocy aż do Zesłania Ducha Świętego, przez wzgląd na Zmartwychwstanie Chrystusa stanowi wyobrażenie przyszłego życia, i w tym czasie wyśpiewujemy Panu chwałę z wielką radością. „Alleluja” bowiem, które w tych dniach Kościół święty powtarza na chwałę Pana, to pieśń niebiańska, tak jak to zapisał Jan Apostoł w Apokalipsie i ukazuje nam chwałę wiecznego życia, kiedy to za przykładem naszego Odkupiciela powstali z martwych, w wiecznej szczę́liwości będziemy bezustannie śpiewać po wieczne czasy wraz ze świętymi aniołami chwałę naszego Stwórcy.

Lecz ponieważ właśnie obchodzimy czas paschalny, rozradujmy się nadzieją, bracia najdrożsi, i przejdźmy do kwestii zasadniczej: abyśmy, jak to już zostało powiedziane we wstępie, stali się godni odebrać nagrodę w dniu ostatecznym. Tak więc orzeźwijmy nasze ciało, aby czystość umysłu nie była zakryta. Powstrzymajmy się od wszelkich uciech, pijaństwa, rozwiązłości i niemoralności, a poświęćmy się raczej rozsądnej trzeźwości i świętej czystości, abyśmy, jeśli nie możemy czegoś osiagnąć cielesną wstrzemięźliwościa, mogli dojść to tego prawością myśli i czystością obyczajów. Słuchajcie mnie, bracia, wszyscy, którzy trwacie w Panu, przemawiam do was słowami apostoła: „Oto noc odchodzi, dzień zaś się zbliża. Porzućcie sprawy ciemności, a przywdziejcie pancerz światłości, abyśmy godnie ukazali się w blasku dnia nie na hulankach i pijaństwie, nie na rozpuście i bezwstydzie, nie na kłótniach i walkach, lecz przyobleczcie się w Pana Jezusa Chrystusa, a nie troszczcie

\footnotetext{
${ }^{25}$ Przekładu dokonano na podstawie wydania J.P. Migne, PL 110, 36-37; thum. Natalia Turkiewicz.
} 
się o cielesne pożądania" (Rz 13, 12-14), abyście mogli przyoblec się w życie wieczne i szatę nieśmiertelności. Aby ją bowiem móc przywdziać, odrodziliście się w chrzcie świętym: „Skoro bowiem zostaliście ochrzczeni w Chrystusie, przyoblekliście się w Chrystusa" (Ga 3,27) i staliście się Jego członkami. Skoro więc jesteście członkami Chrystusa, napominam was, abyście się strzegli, by nie zaprzepaścić tej godności. Wielką bowiem i nieocenioną wartością jest być synami Bożymi, a zatem braćmi Chrystusa. Powiadam wam, wystrzegajcie się ludzi i nie tylko pogan, Żydów czy heretyków, lecz także fałszywych katolików, którzy ustami sławią Boga, lecz ich czyny temu zaprzeczają. Wybierajcie rozważnie, kogo będziecie naśladować, jeśli bowiem zechcecie naśladować tłum, obawiam się, byście nie odstąpili od prawdy. Idąc zatem wąską ścieżką między nielicznymi ludźmi, wybierajcie tych, za którymi będziecie podążać. Niebezpieczna bowiem i wąska jest droga wiodąca do życia, i nieliczni przez nią przechodzą. Szeroka zaś i wygodna jest droga prowadząca do śmierci, i idzie nią wielu (por. Mt 7, 13). Wystrzegajcie się grabieży, oszustwa, krzywoprzysięstwa, odrzućcie wadę pijaństwa, przed nierządem chrońcie się jak przed śmiercią, i to nie przed śmiercią, która wyzwala duszę z ciała, lecz przed taką, w której dusza gorzeć będzie na zawsze wraz z ciałem.

Bracia, po cóż szatan nazywa lekkimi te grzechy, które Chrystus wskazuje jako ciężkie? Diabeł bowiem twierdzi, że grzechy ciała nie są ciężkie. Wolno jeść aż do przesytu, pić i cudzołożyć - i w ten sposób oszukuje. To samo uczynił wobec pierwszego człowieka, któremu Bóg powiedział: „W dniu, w którym zjecie z niego, pomrzecie” (Rdz 3, 3). Przyszedł nieprzyjaciel i rzekł: „Nie pomrzecie, lecz otworzą się wasze oczy i będziecie jak bogowie" (Rdz 3, 5). Ostrzeżenie Boga zostało odrzucone, a obietnica diabła - przyjęta. I na nic się zdały słowa niewiasty: „Wąż mnie zwiódł” (Rdz 3, 13), nie ochroniło usprawiedliwianie się, kara ich nie ominęła. Nie przyjmujcie obietnic diabła, który jest waszym prawdziwym wrogiem, lecz słuchajcie wskazań Chrystusa, który was odkupił i podarował wam wieczne królestwo. Spędzajcie te dni w radości, abyście dostąpili rzeczywistej radości w niebie. Świętujcie Paschę jako przejście, tak jak z Chrystusem i Jego świętymi aniołami będziecie cieszyć się wieczną radością pod panowaniem samego Zbawiciela naszego, który z Ojcem i Duchem Świętym żyje i króluje jako Bóg przez wszystkie wieki wieków. Amen.

\section{Homilia XXI: Na Wniebowstapienie Pańskie ${ }^{26}$}

Umiłowani bracia! Święte teksty, przeznaczone do czytania podczas Mszy świętej w dniu doniosłej uroczystości, którą dziś obchodzimy, wyjaśniają to, co było na początku. Przed czterdziestoma dniami świętowaliśmy bowiem czas Paschy Zmartwychwstania Pańskiego, a dziś świętujemy na pamiątkę Wniebowstapienia naszego Odkupiciela. Zbawiciel nasz po swoim zmartwychwstaniu

\footnotetext{
${ }^{26}$ Przekładu dokonano na podstawie wydania J.P. Migne, PL 110, 42-43; thum. Natalia Turkiewicz.
} 
przez czterdzieści dni objawiał się swoim uczniom i poświadczał prawdziwie przez wiele znaków, że zmartwychwstał. W końcu objawił się Jedenastu przy posiłku, tuż przed swym Wniebowstappieniem, wygłosił proroctwo dla ich umocnienia i wskazał na potęgę wiary, i zapowiedział znaki, które się pojawia, skoro uwierzą w proroctwo, i błogosławiąc ich, obiecał zesłanie Ducha Świętego. Potem zaś na ich oczach uniósł się w górę i obłok zakrył Go przed ich oczyma, wstapił do nieba i zasiada po prawicy Boga; i w takiej samej ludzkiej naturze, w jakiej dziś wstapił do nieba, przyjdzie na końcu czasów, by sądzić żywych i umarłych. Tak też apostołom, oglądającym Wniebowstąpienie Pańskie, przepowiedzieli dwaj aniołowie: „Mężowie z Galilei - rzekli - czemu stoicie i wpatrujecie się w niebo? Ten sam Jezus, który dziś was opuścił, przyjdzie tak samo, jak widzieliście Go wstępującego do nieba" (Dz 1, 1).

Oto, skoro słyszycie, że Pan wstapił do nieba, rozweselcie się w sercach niezmierzoną radością głoście ustami należną cześć i okażcie radość waszą także na twarzy, wspominacie bowiem na majestat Chrystusa i chwałę królestwa niebieskiego. I zaiste mamy wielki, niewysłowiony wręcz powód ku radości, gdy słyszymy i przyjmujemy ufnym sercem, że w obliczu ogromu świętego stworzenia natura ludzka przewyższa godność wszystkich istot niebiańskich, górując nad zastępami anielskimi, i wyniesiona nad wszelkie moce niebieskie, przywiedziona została przed tron Boga Ojca. Albowiem wstapienie Chrystusa jest naszym wyniesieniem i tam, dokąd podazżła wcześniej chwała Głowy, tam również zdąża nadzieja ciała. Cieszmy się przeto słusznie i radujmy się, składając nabożne dziękczynienie. Dziś bowiem nie tylko otrzymaliśmy potwierdzenie, że będziemy żyć w raju, lecz także w Chrystusie przenikniemy wyżyny niebiańskie, wyniesieni na wysokości dzięki łasce Chrystusa, którą utraciliśmy przez nienawiść szatana. Albowiem ci, których jadowity nieprzyjaciel wyrzucił ze szczęśliwości pierwszego mieszkania, tych wcielony Syn Boży umieścił po prawicy Ojca.

Umiłowani, wstąpmy tam tymczasem z Chrystusem w sercu, a gdy ów dzień przyrzeczony nadejdzie, wstapimy tam i ciałem. Powinniśmy jednak wiedzieć, bracia, że wraz z Chrystusem nie wejdzie tam pycha ani chciwość, ani rozpusta, ani zawiść. Żadna z naszych ułomności nie podąży za naszym Lekarzem. Dlatego, jeśli pragniemy iść za Nim, powinniśmy odrzucić wady i grzechy. Te bowiem krępują nas jakby kajdanami i chcą zagarnąc nas jakby siecią w stronę grzeszników. Dlatego też z Bożą pomocą, według słów psalmisty: „Zerwijmy ich więzy” (Ps 2, 3), byśmy spokojnie mogli powiedzieć Panu: „Ty rozerwałeś moje kajdany, Tobie złożę ofiarę pochwalną” (Ps 116, 16-17). Postępując jednak za Panem, nie wywyższajmy się i nie przypisujmy tego własnej zasłudze. Powinniśmy mieć bowiem serce wzniesione, lecz ku Panu, albowiem serce wzniesione, lecz nie ku Panu, nazywa się pychą. Podniesienie serca do Pana natomiast nazywa się schronieniem.

Zobaczcie, bracia, ten wielki cud: Bóg jest wielki, i kiedy się wywyższasz, odsuwa się od ciebie, a gdy się uniżasz - zstępuje do ciebie. Dlaczego tak się 
dzieje? Ponieważ jest wysoko i widzi to, co jest nisko, i nawet to, co wysoko, ogląda z oddalenia. To, co nisko, ogląda z bliska, aby je podnieść. Na to zaś, co wysokie i dumne, patrzy z daleka, aby je uniżyć. Chrystus bowiem zmartwychwstał, aby dać nam nadzieję, że człowiek, który umarł, zmartwychwstanie; abyśmy nie tracili nadziei z powodu śmierci i byśmy nie sądzili, że nasze życie kończy się śmiercią, niespokojni o zbawienie duszy i spokój po śmierci. Wstąpił do nieba na oczach apostołów i siedzi po prawicy Boga, i zaręcza, że nas również umieści po swej prawej ręce. I dlatego teraz powinniśmy wierzyć, aby potem dzięki wierze móc oglądać Boga. Oczyśćmy przez wiarę oczy naszego serca, ponieważ tylko tą drogą możemy ujrzeć Boga. Tak rzecze sama Prawda: „Błogosławieni czystego serca, albowiem będą widzieć Boga” (Mt 5, 8).

Uniżmy się pod potężną ręką Boga, aby nas podniósł w dniu swego przybycia. Ten bowiem, który teraz wstapił cichy i pokorny, wówczas nadejdzie jawnie i z całą surowością. Ogień zapłonie na Jego obliczu, a wokół Niego wielki niepokój, i zasiądzie na tronie swego majestatu i zgromadzą się przed Nim wszystkie ludy, i każdy odbierze swoje według tego, jak czynił - albo dobrze, albo źle. Ci, co czynili dobrze, pójdą do życia wiecznego, ci zaś, co źle postępowali, pójdą w wieczny ogień. On sam więc jest naszą drogą i naszą ojczyzną - jako człowiek jest drogą, jako Bóg - jest ojczyzną. Jeśli biegniemy wiernie, idziemy za Nim, i jeśli wytrwamy w biegu, przyjdziemy do Niego. On sam swoją łaską raczył za nas poręczyć, On, który dziś wstąpił do nieba i dał nam nadzieję życia wiecznego - Jezus Chrystus, który z Ojcem i Duchem Świętym żyje i króluje, Bóg przez wszystkie wieki wieków. Amen.

\section{Homilia XXII: Na Dzień Pięćdziesiq̨tnicy ${ }^{27}$}

Najdrożsi bracia! Im więcej radości czerpiemy z dzisiejszego święta, tym więcej jej pragniemy; im chciwiej spijamy jej słodycz, tym gorętsze pali nas pragnienie. Świętujemy dziś bowiem dzień Pięćdziesiątnicy, czyli pięćdziesiąty dzień od Zmartwychwstania Pańskiego. W tym dniu bowiem Duch, zwany po grecku Paraclitus, czyli Pocieszyciel, według obietnicy Chrystusa zstapił na apostołów i rozpalił ich serca ogniem swojej miłości, i rozjaśnił ich światłem wszechwiedzy, i sprawił, że ogarnęła ich ogromna niebiańska radość wśród ucisku ze strony prześladujących ich Żydów. Przede wszystkim bowiem należy wiedzieć, że dzisiejsza uroczystość uświęcona jest nie tylko przez łaski ewangeliczne, ale także już dawniej została zapowiedziana przez misteria Starego Prawa i z nakazu Pańskiego powinna być obchodzona przez sprawowanie świętych obrzędów. Dzisiejszego dnia bowiem, jak wiemy, zebranym w sali na górze uczniom dał się słyszeć gwałtowny szum z nieba, i Duch Święty pod widzialną postacią ognia obdarzył ich znajomością

27 Przekładu dokonano na podstawie wydania J.P. Migne, PL 110, 43-45; tłum. Natalia Turkiewicz. 
wszystkich języków. Kiedy ów głos się rozległ, zgromadzili się pobożni mężowie, z różnych stron przybyli do Jerozolimy na święto Paschy, i osłupieli w zdumieniu, ponieważ każdy z nich słyszał swój język, w którym uczniowie głosili wielkie dzieła Boże. Po uczniach poznali, że Duch Święty jest łaską, którą mogą dostrzec, obiecaną niegdyś głosem proroków, a teraz zesłaną jako dar przez Chrystusa, i uwierzyło wówczas trzy tysiące mężów, i przez chrzest oni także przyjęli dar Ducha Świętego. Dziś obchodzimy doroczną pamiątkę tego dnia, wiecznie żywe święto tej niebiańskiej łaski. Aby pamięć o tym dniu jeszcze wyraźniej wyryć w sercach wiernych, w Kościele świętym zrodził się przepiękny zwyczaj, aby co roku tego dnia udzielać sakramentu chrztu - po to, by w wiernych, obmytych w zbawczym zdroju, przygotować godną świątynię dla przychodzącego Ducha Świętego. Przez to nie tylko obchodzimy pamiątkę dawnego zdarzenia, ale również na nowo świętujemy zesłanie Ducha Świętego w nowo przyjętych dzieciach.

Niech Wasza Miłość zwróci też uwagę na to, jak z naszym dzisiejszym świętem współgra typ i figura święta obchodzonego w Starym Prawie. Wyzwoleni z niewoli egipskiej synowie Izraela po złożeniu ofiary z baranka paschalnego, szli przez pustynię, by dotrzeć do Ziemi Obiecanej, i przybyli do góry Synaj. Na tej górze Bóg zstąpił w ogniu, przy dźwięku trąb, wśród gromów i błyskawic, a działo się to pięćdziesiątego dnia od Paschy, i potężnym głosem dał im Dziesięcioro Przykazań. I zlecił, by na pamiątkę ustanowienia Prawa tego dnia w kolejnych latach poświęcali na Jego ołtarzu płody ziemi tego roku w postaci dwóch chlebów z pierwocin. Tak też po ofierze prawdziwego Baranka, czyli Chrystusa, albowiem podczas naszej Paschy Chrystus składa siebie w ofierze (por. 1Kor 5, 7), dokładnie pięćdziesiąt dni po tym wydarzeniu, a więc dziś, uczniowie otrzymali łaskę Ducha Świętego podczas przebywania w sali na górze ${ }^{28}$, czyli na wysokości niebiańskich nakazów. Kiedy bowiem na zewnątrz pojawił się widzialny ogień, to w niewidzialny sposób rozjaśnił ich serca światłem wiedzy i rozpalił je nieugaszonym płomieniem miłości. I natychmiast sami apostołowie złożyli świętą ofiarę, zaraz po przyjęciu daru Ducha Świętego. I zamiast dwóch chlebów ofiarowali dwa ludy, ponieważ głosząc Ewangelię wobec tych, co się zebrali, wielu nawrócili ku wierze. I tych, odrodzonych w chrzcie świętym i uświęconych łaską Ducha Świętego, uczniowie przywiedli do wspólnoty ołtarza Pańskiego niby żywe pierwociny Nowego Przymierza.

My zatem, bracia, rozważając te wydarzenia i przyjmując je z czystą duszą i prostą wiarą, oczyśćmy się z wszelkiej cielesnej zmazy, abyśmy mogli zasłużyć na przyjęcie Ducha Świętego. Jeśli więc pozostawimy sprawy tego świata,

${ }^{28} \mathrm{~W}$ tekście oryginalnym: in cenaculo constitutis, id est in sublimitate caelestium praeceptorum. Gra słów trudna do oddania w przekładzie (nawiązująca do usytuowania sali, w której przebywali uczniowie, na górze domu), jeśli cenaculum tłumaczymy przez „wieczernik”; por. Dz 1, 13 (Wlg) - in cenaculum ascenderunt; ale w przekładzie polskim (za greckim oryginałem) czytamy: „weszli do sali na górze”. 
przyjmiemy tego samego Pocieszyciela, co apostołowie, czyli Ducha Prawdy, którego zesłał nam Ojciec. Owo przyjęcie u Boga Ojca nie ma względu na osoby, lecz stanie się nam to, co zostało obiecane apostołom, jeśli w naszych czynach, dążeniach i działaniach będziemy brali przykład z apostołów. Skoro zaś sprawimy, że dusza nasza stanie się czysta i pełna Bożych przykazań, i nie będziemy naruszać Prawa Bożego, to my sami jako dziedzice Boga i współdziedzice Chrystusa z łaską Pana dostapimy wiecznego dziedzictwa i przebywania $\mathrm{z}$ aniołami. Zaklinam was zatem, bracia umiłowani, byście niezachwianie wierzyli w Ojca i Syna, i Ducha Świętego, w jednego Boga w Trójcy i Trójcę w jedności, aby nie utykały nogi waszych zmysłów, oczy wasze nie spoglądały w stronę złego, a ręce nie stały się chciwe. Każdy bowiem, kto nie postępuje według zasad wiary katolickiej, ma ułomne nogi i marnieje z powodu skapstwa swoich rąk. Zatem, bracia, tak postępujcie i czyńcie takie starania, aby żaden z waszych członków nie został dotknięty takim kalectwem. Nie pozwólcie, by srożyła się w was pożądliwość, nie odstraszajcie chciwością, niech was nie osłabia wiarołomstwo, abyście, niesplamieni i czyści aż do głębi stali się mieszkaniem Boga, zaś Duch Swięty, który, jak czytamy, zstapił dziś na apostołów, niech raczy stale w was przebywać. Przez Pana naszego Jezusa Chrystusa, który zapowiedział zesłanie Ducha Świętego i który króluje z Ojcem w jedności Ducha Świętego przez wszystkie wieki wieków. Amen.

\section{Homilia XXVI: Narodzenie św. Jana Chrzciciela ${ }^{29}$}

Już dzięki łaskawości Pana, bracia najdrożsi, przyszło nam obchodzić bardzo wyczekiwane święto i dlatego wszyscy, którzy z właściwym oddaniem przygotowali się do tak wielkiej uroczystości poprzez dobre uczynki, tym śmielej niech wyrażają radość. Ci zaś, którzy okazali się nazbyt leniwi, by to uczynić, niech przynajmniej teraz z większą gorliwością, ze łzami i skruchą błagają o Boże miłosierdzie, by nie utracili na wieki doskonałej radości zbawionych. Dziś, bracia, obchodzimy święto narodzenia Jana Chrzciciela, co - jak czytamy - nigdy nie zostało przyznane żadnemu spośród świętych. $\mathrm{Na}$ całym świecie bowiem jest uroczyście obchodzony jedynie dzień narodzin Pana i św. Jana. I słusznie, gdyż jedne i drugie narodziny są pełne tajemnicy. Jana zrodziła niepłodna, Chrystusa poczęła dziewica. W Elżbiecie zostaje pokonana niepłodność, w świętej Maryi Dziewicy zmienia się sposób poczęcia. Elżbieta urodziła syna mając męża, Maryja uwierzyła [słowom] anioła i poczęła człowieka. Elżbieta poczęła człowieka, ale tylko człowieka. Maryja zaś Boga i człowieka. Wielki jest zatem Jan, jego wielkości sam Zbawiciel daje świadectwo mówiąc: „Nie powstał między narodzonymi z niewiast większy od Jana Chrzciciela” (Mt 11, 11). Przewyższa bowiem wszystkich razem,

${ }^{29}$ Przekładu dokonano na podstawie wydania J.P. Migne, PL 110, 50-52; tłum. Agnieszka Strycharczuk. 
wyprzedza proroków, góruje nad patriarchami i każdy zrodzony z niewiasty jest mniejszy od Jana. Ten, który narodził się z Dziewicy większy jest niż on. Dlatego sam Jan mówi: „On jest tym, który po mnie przyjdzie, który stał się przede mna, a któremu ja nie jestem godzien rozwiązać rzemyka u jego sandała” (J 1,27) oraz: „Z Jego pełności wszyscy otrzymaliśmy łaskę po łasce” (J 1, 17). Ponieważ każdy dostrzegł, że on sam i wszyscy ludzie żyją dzięki łasce, dlatego nikogo jako nie potrzebującego [łaski] z tej liczby nie wyłączył, zwłaszcza że mówił: my wszyscy, prorocy, patriarchowie, apostołowie, wielu świętych i posłani przed wcieleniem lub posłani przez Wcielonego, my wszyscy otrzymaliśmy z Jego pełności. My jesteśmy naczyniami, On jest źródłem; On jest Stworzycielem, my stworzeniem; On Bogiem, my ludźmi.

Oto, bracia, jest tajemnica w narodzeniu tego, który poprzedził Pana i w narodzeniu naszego Odkupiciela, ponieważ narodzenie proroka wskazuje na nasze uniżenie, narodzenie Pana na nasze wywyższenie. Jan przyszedł na świat, gdy dnia ubywało, Chrystus zaś, gdy dnia zaczęło przybywać, ponieważ właściwym było, aby chwała człowieka zmniejszała się a chwała Boga zwiększała. Jan mając podobne odczucie mówi: „Trzeba, bym ja się umniejszał, zaś On wzrastał" (J 3, 30). To także znalazło wypełnienie w śmierci obydwu: by człowieka pomniejszyć - ścięto głowę Janowi, by wywyższyć Boga - Chrystusa zawieszono na drzewie krzyża. $Z$ jakiego zaś powodu Pan nasz i Zbawiciel powiedział, że św. Jan jest pochodnią i dlaczego zechciał posłać go przez soba, pokrótce wyjawię Waszej Miłości. Jan został wysłany niczym głos przed słowem, pochodnia przed słońcem, herold przed sędzią, sługa przed panem, przyjaciel przed oblubieńcem. A ponieważ ciemności grzechu i mrok niewiary ogarnęły cały świat i nie pozwalały dostrzec światła sprawiedliwości, święty Jan zostaje posłany niczym pochodnia, aby oczy serca, które zaślepione ropą nieprawości nie mogły ujrzeć wielkiego i prawdziwego światła, najpierw przyzwyczajały wzrok do płomienia pochodni jako delikatnego blasku, i powoli usunąwszy ciemności grzechów oraz oczyściwszy się z błota niewiary, wraz z przyjściem Chrystusa mogły przez to światło z nieba raczej doznać radości niż udręczenia. Bowiem jak zaropiałe oczy zmuszasz do patrzenia, gdy kierujesz wzrok na nikły blask płomienia, i doznajesz dotkliwszej udręki gdy wzniecasz intensywne światło, tak Pan nasz i Zbawiciel, który jest prawdziwym światłem, gdyby wcześniej nie wysłał św. Jana niczym pochodni, cały świat nie mógłby przyjąć Jego blasku. Oto dlaczego uznaliśmy, że święty sługa, który zapowiedział przybycie Pana jest pochodnią. On wyprzedził prawdziwą światłość i dał świadectwo o światłości, by wszyscy uwierzyli przez niego. Biegnijmy do niego, słuchajmy jego słów, on właśnie jest głosem jak mówi prorok Izajasz: „Głos wołającego na pustyni: «Przygotujcie drogę Panu, czyńcie prostymi Jego ścieżki. Każda dolina będzie podniesiona, a każda góra i pagórek będzie obniżony; i krzywe drogi staną się prostymi, a strome gładkimi, i wszelkie stworzenie ujrzy chwałę Pana»" (Iz 40, 3-5). 
Także i my przygotujmy drogę dla Pana, który pragnie przyjść do naszych serc. Usuńmy przeszkody grzechów przez ich wyznanie i pokutę. Uczyńmy prostymi ścieżki naszego życia, które przedtem były krzywe i kręte. Wyrównajmy drogę dla prawdziwej wiary przez dobre uczynki, niech zostanie odrzucona pycha światowa i usunięta trwożliwa małoduszność. W ten sposób, po ukształtowaniu, uporządkowaniu, unormowaniu, zjednoczeniu wszystkiego, zobaczymy Boże zbawienie jak jest napisane: „Bo w pokoju stało się jego miejsce, i mieszkanie jego na Syjonie" (Ps 76, 3). Niech On, ubłagany prośbami swego Poprzednika, pozwoli nam radować się wiecznym oglądaniem [siebie], On, który po to zstąpił z nieba, i zwyciężając śmierć wstąpił do nieba, Jezus Chrystus nasz Zbawiciel, który z Ojcem i Duchem Świętym żyje i króluje Bóg przez wszystkie wieki wieków. Amen.

\section{Homilia XXVII: We wspomnienie męczeństwa apostotów Piotra i Pawla}

Dziś, bracia najdrożsi, na całym świecie jest obchodzone bardzo znane wspomnienie męczeństwa świętych apostołów Piotra i Pawła. W jakiej części świata mogła pozostać nieznana tak wielka dla nich cześć, skoro dzięki świadectwu cnót wszędzie głosi się wielkość ich chwały? Mówi o nich przecież prorok Dawid: „Ich głos się rozchodzi po całej ziemi i na krańce świata ich słowa" (Ps 19, 5). Po całej ziemi głosi się moc cudownych dzieł Piotra i do najdalszych jej części dotarły listy Pawła. Któż bowiem nie słyszał, że św. Piotr apostoł przywrócił zdrowie chromemu od urodzenia, od dawna cierpiącemu na chorobę nóg, który siedział przy bramie świątynnej zwanej Piękną, aby to, czego nie dopełniła natura, przywróciła łaska apostolska? Albo też w jakim miejscu nie znają listów Pawłowych? Gdzie nie czyta się słów apostoła Pawła i któż $\mathrm{z}$ wiernych nie utrwalił ich na piśmie, nie przechowuje w sercu, nie wyraża sposobem życia? Tenże Paweł został nazwany przez Pana wybranym naczyniem. Dobre naczynie, w którym są przechowywane drogocenne skarby pouczeń Pana. Zaiste dobre naczynie, które jest wypełnione i z którego pełni nieustannie wypływa dla ludzkości pokarm życiowy.

A zatem, bracia, słusznie Pan Jezus tych dwóch apostołów zechciał wyróżnić spośród grona swych świętych, ich też swym postanowieniem przeznaczył do tak wielkiej chwały. Piotrowi bowiem, jako dobremu zarządcy, powierzył klucze królestwa niebieskiego; z Pawłem zaś, jako znakomitym uczonym, połączył przekaz nauki Kościoła, aby ci, których skierował ku zbawieniu, Piotr przyjmował do wiecznego pokoju; by Paweł wyjawił ich sercom słowa nauki, zaś Piotr otworzył ich duszom królestwo niebieskie. Tak więc święci Piotr i Paweł wyróżniają się w gronie wszystkich apostołów i przewyższają [ich] pewnym szczególnym rodzajem pierwszeństwa. $\mathrm{W}$ istocie trudno dociec, kto

${ }^{30}$ Przekładu dokonano na podstawie wydania J.P. Migne, PL 110, 52-54; tłum. Agnieszka Strycharczuk. 
kogo wśród nich przewyższa. Sądzę bowiem, iż oni są równi pod względem zasług, gdyż są równi męczeństwem. Żyli oni podobnym oddaniem dla wiary, i widzimy też, że razem doszli do chwały męczeństwa. Nie bez powodu bowiem przyjmujemy fakt, że $w$ tym samym dniu, $w$ tym samym miejscu poddali się wyrokowi tego samego tyrana. W tym samym dniu zostali umęczeni, aby równocześnie dojść do Chrystusa. W jednym miejscu, aby nie stało się tak, że drugi miałby zginąć nie w Rzymie. Pod jednym prześladowca, by każdy jednakiego okrucieństwa doświadczył.

Dzień zatem został wybrany dla uwydatnienia zasługi, miejsce dla chwały, prześladowca dla męstwa. A w jakim to miejscu ponieśli śmierć męczeńską? W mieście Rzymie, które posiada godność pierwszeństwa i stolicy narodów, aby tam, gdzie mieściło się siedlisko zgorszenia, trwała w pokoju stolica świętości, i aby tam, gdzie zamieszkiwali władcy pogańscy, przebywali rządzący Kościołem. Z czego płynęła zasługa świętych Piotra i Pawła, możemy wnosić stąd, iż Pan uświetnił własną męką Wschód świata, Zachód zaś, by go w żaden sposób nie pomniejszyć, zamiast swoją krwią własną, krwią apostołów zechciał wyróżnić. A choć Jego męka przyniosła nam zbawienie, to jednak śmierć obydwu męczenników posłużyła nam za przykład. W dniu dzisiejszym święci apostołowie przelali krew, lecz zwróćmy uwagę na przyczynę, dla której znieśli to męczeństwo. Chodzi o to, że wśród pozostałych cudów także ów Szymon Mag dzięki ich modlitwom z powietrznych przestworzy został gwałtownie zrzucony na ziemię. Gdy bowiem tenże Szymon nazwał siebie Chrystusem i utrzymywał, że tak jak Syn do Ojca, może on - unosząc się - wstąpić na wyżyny, i gdy nagle uniesiony dzięki magicznym sztuczkom zaczął krążyć w powietrzu, wtedy Piotr upadłszy na kolana modlił się do Pana i dzięki świętej modlitwie pokonał magiczną podstępność. Pierwej też dotarła do Boga modlitwa niż sama umiejętność unoszenia się i wcześniej doszła prawa prośba niż zgubne domniemania. Pierwej - powiem - Piotr stojący na ziemi uzyskał to, o co prosił, niż Szymon dotarł do niebios, które chciał posiąść; wyżej dotarła pokora niż pycha; skuteczniej przeniknęła do niebiańskich głębi miłość niż pełna pychy niegodziwość.

Następnie sama męka, choć w każdym odmienna, jednak wypełniona jest jednakową świętością łaski. Piotr bowiem, tak jak Zbawiciel, poniósł kaźń krzyża i nawet w śmierci nie różnił się od ofiary Pańskiej, aby w męce upodobnić do Tego, którego naśladował dzięki wierze. Pawłowi zaś ścięto głowę mieczem, ponieważ uznano, że był dla narodów głową wiary, aby ukazać wiernym poprzez ścięcie głowy prawdziwą Głowę, którą jest Chrystus i której nie można $\mathrm{w}$ jakikolwiek sposób oddzielić.

Oto, bracia, jak wielkich mamy patronów, jakich przewodników naszej wiary, jakich współuczestników naszej radości. I dlatego za każdym razem, gdy obchodzimy wspomnienie świętych apostołów czy też świadków Chrystusa, pozostawiwszy wszelkie życiowe zajęcia, gromadźmy się bez jakiejkolwiek zwłoki. Oddajmy cześć tym, którzy nabyli dla nas zbawienie przez wylanie własnej 
krwi, którzy jako najświętszą ofiarę złożyli siebie Panu dla naszego pojednania, zwłaszcza, że wszechmogący Bóg mówi: „Kto was słucha, mnie słucha; a kto wami gardzi, mną gardzi” (Łk 10, 16). Uczcijmy uroczystym obchodem świętych apostołów i świadków Chrystusa, uczcijmy pochwalnymi hymnami, uczcijmy modlitwą, uczcijmy także przez podobne świadectwo życia. A tak przez ich wstawiennictwo dojdziemy do wiecznej wspólnoty radości za sprawą Twórcy i Dawcy wszelkich dóbr, Pana Jezusa Chrystusa, który z Ojcem żyje i króluje w jedności Ducha Świętego, Bóg przez wszystkie wieki wieków. Amen.

\section{Homilia XXVIII: W Narodzenie Świętej Maryi ${ }^{31}$}

Najmilsi! Nadszedł długo wyczekiwany przez nas dzień narodzenia błogosławionej i godnej czci Maryi zawsze Dziewicy, dlatego niechaj w niezmiernym uniesieniu cieszy się nasza ziemia rozjaśniona narodzeniem tak wielkiej Dziewicy. Przez Jej przyjście na świat zmienia się natura stworzenia, dzięki Niej zostaje także zmazana wina. W Niej bowiem został pokonany ów wyrok zapowiedzianego cierpienia, który mówi: „w bólu będziesz rodziła dzieci” (Rdz 3, 16), ponieważ Ona w radości wydała na świat Pana. Ewa bowiem przyniosła żałobę, Ona przyniosła radość; Ewa nosiła w łonie łzy, Maryja - radość, ponieważ Ona wydała na świat niewinnego, tamta zaś grzesznika. Jako dziewica porodziła i dziewica po zrodzeniu pozostała. Podwójny cud, bracia, ponieważ brzemienna została bez skazy cielesnej i w porodzeniu pozostała dziewica.

„Witaj” - mówi do niej Anioł, ,pełna łaski, Pan z Tobą” (Łk 1, 28). Pan z Tobą w sercu, z Tobą w łonie, z Tobą w żywocie, z Tobą w niesieniu pomocy. Ciesz się, szczęśliwa Dziewico, Chrystus Król ze swego niebieskiego pałacu znalazł się w Twoim łonie; i dlatego będziesz błogosławiona między niewiastami, która dałaś życie i mężom, i niewiastom. Matka rodzaju ludzkiego przyniosła światu cierpienie, Rodzicielka naszego Boga dała światu zbawienie; pierwsza dała śmierć, druga dała życie; ze względu na nieposłuszeństwo wzmaga się posłuszeństwo. Tak więc szczęśliwa Maryja trzyma Dziecię, radując się obejmuje Syna, niesie Tego, przez którego była niesiona. Słuchajcie zatem dźwięku Jej słów, gdy mówi: „Wielbi dusza moja Pana i raduje się duch mój w Bogu, Zbawicielu moim. Gdyż wejrzał na uniżenie swojej służebnicy; oto bowiem odtąd wszystkie narody będą nazywać mnie błogosławioną. Albowiem wielkie rzeczy uczynił mi Ten, który jest Wszechmocny" (Łk 1, 46-49).

Wreszcie po owej godnej błogosławieństwa zapowiedzi, kiedy milcząca Dziewica zmagała się wewnętrznie z różnymi myślami, [rozważając], co oznacza to pozdrowienie, niebieski posłaniec mówi: „Nie bój się Maryjo, albowiem znalazłaś łaskę u Boga! Oto poczniesz i porodzisz Syna, i nazwiesz go imieniem Jezus” (Łk 1, 30-31). Na to Ona: „Jakże się to stanie, skoro nie

${ }^{31}$ Przekładu dokonano na podstawie wydania J.P. Migne, PL 110, 54-55; tłum. Agnieszka Strycharczuk. 
znam męża?” (Łk 1, 34). Anioł Jej odpowiada: „Duch Święty zstąpi na ciebie i moc Najwyższego osłoni cię. Dlatego też Święte, które z Ciebie się narodzi, będzie nazwane Synem Bożym” (Łk 1, 35). Anielski poseł wraca bez zwłoki, a do dziewiczej komnaty wstępuje Chrystus.

Cieszmy się zatem i my, bracia, w dniu [narodzenia] tak zacnej Dziewicy, która otrzymała łaskę jako jedyna spośród wszystkich niewiast, by przyjąć do swego dziewiczego łona, do czystych i świętych wnętrzności, Króla, którego niebiosa, ziemia i morze nie mogą przyjąć, by sama jako miłościwa Pośredniczka wstawiała się za nami u Syna, który Ją przeniósł w pełni chwały do niebieskiego pałacu, a która teraz wraz z Nim żyje i króluje na wieki wieków. Amen.

\section{Homilia XXIX: We Wniebowzięcie Świętej Maryi Dziewicy ${ }^{32}$}

Skoro uroczystości wszystkich świętych dziewic, które zachowały czystość duszy i ciała aż do końca życia oraz dzięki Bożemu miłosierdziu odniosły zwycięstwo na tym marnym świecie, są godne pochwały, rozważcie, bracia, jakiej czci godna jest ta właśnie uroczystość, w której Dziewica nad dziewicami przeszła z tego ziemskiego życia do chwały wiecznej. Ponieważ nie tylko wierzymy, że Ona jest godna wspominania wśród nas, lecz także staje się wielce czcigodna wśród świętych duchów anielskich. Stąd one z wymowną radością się weselą, gdy widzą że Matka Pana i Najwyższego Stworzyciela przebywa wraz z nimi w wiecznej szczęśliwości. [Widza] Matkę, czyli Tę, która poczęła Syna w łonie i zachowała czystość; zrodziła Syna i pozostała dziewicą. Matka niepokalana, Matka nienaruszona, Matka nietknięta, Matka Jednorodzonego Syna i Króla wszystkich, Dawcy i Stworzyciela wszystkiego - Tego, który w niebiosach jest bez Matki, na ziemi bez Ojca; Tego, który w niebie zgodnie ze swoim Bóstwem przebywa w łonie Ojca, a na ziemi zgodnie z przyjętym ciałem był w łonie Matki. Dlatego Dziewica Maryja jest nazywana Matką Tego Jednorodzonego Boga, godna - godnego, niepokalana - świętego, jedna - jednego, jedyna - jedynego. Żaden inny Jednorodzony Bóg nie przyszedł na ziemię, ani też żadna dziewica nie wydała na świat jednorodzonego. Stąd podziwiając Jej wielkość, milczącymi głosami serca, w taki właśnie sposób, bracia najdrożsi, wykrzykujmy na chwałę i wołajmy: O zaiste błogosławiona Dziewico Maryjo, poznaj swoją chwałę, właśnie tę chwałę, którą zwiastował Ci Anioł oraz przepowiedział Jan przez usta Elżbiety, jeszcze nie matki, zanim wyszedł z jej łona: „błogosławiona jesteś między niewiastami i błogosławiony owoc Twojego łona" (Łk 1, 42). Ty także zyskałaś łaskę, by przyjąć przyjście Syna obiecanego całemu światu od tylu wieków. Zostałaś przeznaczona na mieszkanie niezmierzonej wielkości, sama przez dziewięć miesięcy dzięki szczególnemu przywilejowi nosiłaś nadzieję świata, chwałę ludzkości,

${ }^{32}$ Przekładu dokonano na podstawie wydania J.P. Migne, PL 110, 55-56; thum. Agnieszka Strycharczuk. 
powszechną radość wszystkich. Pan wszelkiego początku od Ciebie wziął początek i aby wylać krew za życie świata z Twego ciała [ja] przyjął. Z jednego Twego [aktu] zrodzenia powstało życie dla wszystkich pokoleń, zyskałaś łaskę, by Twórcę aniołów nazywać swoim Synem. Oto zostałaś wywyższona nad chóry aniołów, szczęsna Matko, obok królewskiego Syna będziesz jako Królowa panować na wieki. A Ten, któremu udzieliłaś gościny w swym łonie sam przekazał Tobie królestwo nieba.

Lecz gdy to mówię, bracia, odnoszę wrażenie, że wszelka pochwała jest mniejsza od Jej chwały i wszelka mowa ustępuje przed czcią względem Niej. Niech Ją wychwalają chóry aniołów, wysławiają archaniołowie, wszystkie moce niebieskie i zgromadzenie świętych niech radośnie wykrzykuje Jej chwałę. A jednak wydaje mi się, że wciąż Jej godność wybija się ponad składane Jej hołdy. Rozważając to, bracia, nie traćmy nadziei i nie czyńmy zaniechania, co więcej, w miarę naszych możliwości podnieśmy głosy na Jej cześć, z zapałem przystąpmy do głoszenia Jej chwały, ponieważ to, co nie jest w naszej możności dopełni łaskawość Jej serca. Oczyśćmy nasze sumienia ze zgubnych przywiązań i przygotujmy się do wyznawania tak czcigodnego imienia. Każdy człowiek i ludzie każdego wieku niech starają się przyozdobić w dobre postępowanie, a do czego został wezwany, w tym niech stara się wytrwać. Zatem wszyscy mężowie i niewiasty, którzy zachowują zobowiązanie do życia w czystości, niech wytrwale pozostają mu wierni, by okazali się świętymi i ciałem i duchem. Niech pamiętają o Bożej nauce, niech zachowują sprawiedliwość wraz z pobożnością, niech będą stali w wierze, pokorni w bojaźni, mężni w znoszeniu wszystkiego, łagodni w doświadczaniu przeciwności, skorzy do czynów miłosierdzia, jednomyślni i zgodni w braterskim pokoju i zawsze ochoczy do wszelkich dobrych czynów. Ci zaś, którzy żyją w małżeństwie, niech mimo tego zachowują czystość w ugruntowanej wierze, zgodnie z którą cały Kościół jest nazywany oblubienicą Boga. Ponieważ jednak Kościół katolicki, który składa się z żyjących w czystości dziewcząt i chłopców, z zamężnych kobiet i żonatych mężczyzn, został nazwany jednym imieniem - dziewicy, wsłuchaj się w słowa apostoła, który mówi: „Poślubiłem was, aby przedstawić was jako czystą pannę jednemu mężowi - Chrystusowi" (2Kor 11,2). Niech zachowują wierność małżeńską, niech się powstrzymują od nieprawości, czynią dobre dzieła, przestrzegają gościnności i nie ociągają się w dawaniu jałmużny. Ci, którzy wydają się być bogatymi na tym świecie, niech nie postępują $\mathrm{z}$ wyższością i nie pokładają nadziei $\mathrm{w}$ niepewnych dobrach, lecz w żywym Bogu, który hojnie każdemu udziela. Niech uczą się właściwie postępować, stawać się bogatymi w dobre uczynki, poczuwać się do uprzejmego współdziałania z bliskimi, niech kładą dla siebie dobry fundament, aby osiagnęli życie wieczne. Ci zaś, którzy są ubodzy, niech nie opuszczają się w wierze, lecz niech czynią wysiłki, by stać się bardziej bogatymi w cnoty, jak zostało napisane: „Czyż Bóg nie wybrał ubogich na tym świecie na bogatych w wierze i dziedziców królestwa, które Bóg obiecał tym, którzy 
go miłują?” (Jk 2, 5), a prorok mówi: „Byłem młody i zestarzałem się, a nie widziałem sprawiedliwego opuszczonego, ani potomstwa jego, które szukałoby chleba" (Ps 36, 25).

Zatem, czy to szlachetnie urodzeni, czy ludzie prości, czy niewolnicy, czy wolni, czy to mężczyźni czy kobiety, czy młodzi czy starsi, wszyscy tak samo słuchajmy apostoła, który mówi: „Trwajcie w wierze, mężnie działajcie i wzmacniajcie się. Wszystkie wasze sprawy niech dokonują się w miłości” (1Kor 16, 13-14). A jeśli święta Boża Rodzicielka zobaczy, że my, którzy właśnie tak postępujemy, bierzemy udział w Jej święcie, z łatwością wyjedna nam i stosowne pocieszenie na chwilę obecną i życie wieczne w przyszłości. Za sprawą Pana naszego Jezusa Chrystusa, który żyje i króluje z Bogiem Ojcem w jedności Ducha Świętego, Bóg przez wszystkie wieki wieków. Amen.

z języka łacińskiego przełożyli ks. Jarosław Adamiak, ks. Tadeusz Gacia, Agnieszka Strycharczuk i Natalia Turkiewicz; wyboru homilii dokonał, tłumaczenie przejrzał, wstępem poprzedził oraz najniezbędniejszymi objaśnieniami opatrzył ks. Tadeusz Gacia*

* Ks. dr hab. Tadeusz Gacia, prof. KUL - kierownik Katedry Literatury Łacińskiej Antyku Chrześcijańskiego i Czasów Nowożytnych w Instytucie Filologii Klasycznej na Wydziale Nauk Humanistycznych Katolickiego Uniwersytetu Lubelskiego Jana Pawła II, e-mail: tadeuszgacia@ kul.lublin.pl; ks. mgr Jarosław Adamiak - doktorant przy Katedrze Literatury Łacińskiej Antyku Chrześcijańskiego i Czasów Nowożytnych w Instytucie Filologii Klasycznej na Wydziale Nauk Humanistycznych Katolickiego Uniwersytetu Lubelskiego Jana Pawła II, e-mail: herezjarha@wp.pl; dr Agnieszka Strycharczuk - starszy wykładowca w Studium Praktycznej Nauki Języków Obcych w Katolickim Uniwersytecie Lubelskim Jana Pawła II, e-mail: agnieszka.strycharczuk@kul.lublin.pl; mgr Natalia Turkiewicz - doktorantka przy Katedrze Literatury Łacińskiej Antyku Chrześcijańskiego i Czasów Nowożytnych w Instytucie Filologii Klasycznej na Wydziale Nauk Humanistycznych Katolickiego Uniwersytetu Lubelskiego Jana Pawła II, e-mail: n.turkiewicz1102@gmail.com. 